\title{
Pleistocene-Holocene vicariance not Anthropocene landscape change, explains the genetic structure of American black bear (Ursus americanus) populations in the American Southwest and northern Mexico
}

\author{
Matt Gould ${ }^{1}$, James Cain III $^{1}$, Todd Atwood ${ }^{2}$, Larisa Harding ${ }^{3}$, Heather Johnson ${ }^{2}$, Dave \\ Onorato $^{4}$, Frederic Winslow ${ }^{5}$, and Gary Roemer ${ }^{1}$ \\ ${ }^{1}$ New Mexico State University \\ ${ }^{2}$ US Geological Survey Alaska Science Center \\ ${ }^{3}$ Arizona Game and Fish Department \\ ${ }^{4}$ Florida Fish and Wildlife Conservation Commission \\ ${ }^{5}$ New Mexico Department of Game and Fish
}

February 7, 2022

\begin{abstract}
The phylogeography of the American black bear (Ursus americanus) is characterized by isolation into glacial refugia, followed by population expansion and genetic admixture. Anthropogenic activities, including overharvest, habitat loss, and transportation infrastructure, have also influenced their landscape genetic structure. We describe the phylogeography of the American black bear in the American Southwest and northern Mexico and investigate how prehistoric and contemporary forces shaped genetic structure and influenced gene flow. Using a suite of microsatellites and a sample of 550 bears, we identified 14 subpopulations organized hierarchically following the distribution of ecoregions and mountain ranges containing black bear habitat. The pattern of subdivision we observed is more likely a product of postglacial habitat fragmentation during the Pleistocene and Holocene, rather than a consequence of contemporary anthropogenic barriers to movement during the Anthropocene. We used linear mixed-effects models to predict genetic distance among individuals, which indicated that both isolation by resistance and geographic distance govern gene flow. Gene flow was highest among subpopulations occupying large tracts of contiguous habitat, was reduced among subpopulations in the Madrean Sky Island Archipelago, where montane habitat exists within a lowland matrix of arid lands, and was essentially nonexistent between two isolated subpopulations. We found significant asymmetric gene flow supporting the hypothesis that bears expanded northward from a Pleistocene refugium located in the American Southwest and northern Mexico and that major highways were not yet affecting gene flow. The potential vulnerability of the species to climate change, transportation infrastructure, and the U.S.-Mexico border wall highlights conservation challenges and opportunities for binational collaboration.
\end{abstract}

This draft manuscript is distributed solely for purposes of scientific peer review. Its content is deliberative and predecisional, so it must not be disclosed or released by reviewers. Because the manuscript has not yet been approved for publication by the U.S. Geological Survey, it does not represent any official findings or policy.

26 January 2022

Matthew J. Gould

Department of Fish, Wildlife and Conservation Ecology 
New Mexico State University P.O. Box 30003, MSC 4901 Las Cruces, New Mexico 88003

mjgould4@gmail.com

Article type: Original article

Pleistocene-Holocene vicariance not Anthropocene landscape change, explains the genetic structure of American black bear (Ursus americanus) populations in the American Southwest and northern Mexico

MATTHEW J. GOULD ${ }^{1,2}$, , JAMES W. CAIN, III ${ }^{1,2,3}$, TODD C. ATWOOD ${ }^{4}$, LARISA E. HARDING ${ }^{5}$, HEATHER E. JOHNSON ${ }^{4}$, DAVE P. ONORATO ${ }^{6}$, FREDERIC S. WINSLOW ${ }^{7}$, GARY W. ROEMER ${ }^{1,2, \delta}$

${ }^{1}$ Department of Fish, Wildlife and Conservation Ecology, New Mexico State University, Las Cruces, NM 88003, USA

${ }^{2}$ Department of Biology, New Mexico State University, Las Cruces, NM 88003, USA

${ }^{3}$ U.S. Geological Survey New Mexico Cooperative Fish and Wildife Research Unit, New Mexico State University, Las Cruces, NM 88003, USA

4 U.S. Geological Survey, Alaska Science Center, Anchorage, AK 99508, USA

${ }_{5}$ Arizona Game and Fish Department, Phoenix, AZ 85086, USA.

${ }^{6}$ Fish and Wildlife Research Institute, Florida Fish and Wildlife Conservation Commission, Naples, Florida 34114, USA

${ }^{7}$ New Mexico Department of Game and Fish Santa Fe, NM 87507 USA

Corresponding authors: mjgould4@gmail.com

Present Address: + U.S. Geological Survey, Northern Rocky Mountain Science Center, Bozeman, MT, 59715 USA. ${ }^{\delta} 712$ Stone Canyon Drive, Las Cruces, NM 88011

\section{ABSTRACT}

The phylogeography of the American black bear (Ursus americanus) is characterized by isolation into glacial refugia, followed by population expansion and genetic admixture. Anthropogenic activities, including overharvest, habitat loss, and transportation infrastructure, have also influenced their landscape genetic structure. We describe the genetic structure of the American black bear in the American Southwest and northern Mexico and investigate how prehistoric and contemporary forces shaped genetic structure and influenced gene flow. Using a suite of microsatellites and a sample of 550 bears, we identified 14 subpopulations organized hierarchically following the distribution of ecoregions and mountain ranges containing black bear habitat. The pattern of subdivision we observed is more likely a product of postglacial habitat fragmentation during the Pleistocene and Holocene, rather than a consequence of contemporary anthropogenic barriers to movement during the Anthropocene. We used linear mixed-effects models to predict genetic distance among individuals, which indicated that both isolation by resistance and geographic distance govern gene flow. Gene flow was highest among subpopulations occupying large tracts of contiguous habitat, was reduced among subpopulations in the Madrean Sky Island Archipelago, where montane habitat exists within a lowland matrix of arid lands, and was essentially nonexistent between two isolated subpopulations. We found significant asymmetric gene flow supporting the hypothesis that bears expanded northward from a Pleistocene refugium located in the American Southwest and northern Mexico and that major highways were not yet affecting gene flow. The potential vulnerability of the species to climate change, transportation infrastructure, and the U.S.-Mexico border wall highlights conservation challenges and opportunities for binational collaboration.

\section{KEYWORDS}


American black bear, American Southwest, northern Mexico, population genetic structure, Pleistocene, Ursus americanus

\section{1 | INTRODUCTION}

The Pleistocene epoch (2.6-0.012 mya) represents a geologic period characterized by massive climatic fluctuations that drove dynamic glacial-interglacial cycles with profound effects on the global distribution and genetic structure of flora and fauna (Hofreiter \& Stewart, 2009). Glacial advance contracted species' ranges into refugial pockets of habitat where isolation, selection and genetic drift resulted in genetic differentiation among populations. Upon glacial recession, species expanded out of their respective refugia into their current distribution resulting in latitudinal patterns of species assemblages, genetic structure, and areas of admixture between formerly isolated populations (Lomolino, Brown, \& Davis, 1989; Puckett, Etter, Johnson, \& Eggert, 2015; Shafer, Cullingham, Côté, \& Coltman, 2010). The phylogeographic influence of these glacial-interglacial dynamics has been observed for vagile species like the gray wolf (Canis lupus ; Weckworth, Talbot, \& Cook, 2010), woodland caribou (Rangifer tarandus caribou ; Klütsch, Manseau, \& Wilson, 2012), and red fox (Vulpes vulpes; Aubry, Statham, Sacks, Perrine, \& Wisely, 2009) and for more habitat-restricted species like the American marten (Martes americana; Stone, Flynn, \& Cook, 2002). The location of refugia is highly dependent on the life history of the organism.

The American black bear (Ursus americanus; hereafter, black bear) is a large omnivore endemic to the forests of North America. Its distribution and genetic structure has been an ebb and flow of isolation and admixture events dictated by glacial tides of the Pleistocene (Puckett et al., 2015). Mitochondrial and nuclear data indicate that black bears were last isolated during the Last Glacial Maximum (LGM) 26.5 kya and had contracted into three glacial refugia located in Beringia, the Pacific Northwest, and the American Southeast and a fourth hypothesized refugium in the southwestern United States and northern Mexico (hereafter, the Southwest; Puckett et al., 2015; Varas-Nelson, 2010). As glaciers receded ( 20 kya), black bears expanded out of their respective refugia resulting in admixture among populations in west-central and east-central North America and the formation of region-specific subpopulations (Pelletier, Obbard, White, Doyle, \& Kyle, 2011; Puckett et al., 2015). Black bears across their northern range are genetically diverse and inhabit a large, contiguous landscape with a genetic structure that is consistent with isolation by distance due to femalebiased philopatry (Pelletier et al., 2017, 2011). The hypothesis of the existence of a southwestern refugium is based on limited geographic sampling: Puckett et al. (2015) sampled only 15 bears from a large geographic area representing three states (Arizona, New Mexico and Colorado) in the Southwest, whereas Varas-Nelson (2010) had a larger genetic sample ( $\mathrm{n} 110$ samples for mtDNA and microsatellite analyses) but these were collected from a relatively limited geographic area representing the Sky Islands in southeastern Arizona and northern Mexico.

The potential existence of a southwestern refugium for black bears is independently supported by paleoecological reconstruction based on macrofossils and palynology of woodrat (Neotoma spp.) paleomiddens (Betancourt, Van Devender, \& Martin, 1990). Woodrats collect plant material and pollen is blown into middens with the macrofossils and pollen becoming encased in crystallized woodrat urine, or amberat, that together form an indurated paleomidden (Spaulding, Betancourt, Croft, \& Cole, 1990). Investigations of these paleomiddens reveal information about the relative abundance, distribution, and species composition of prehistoric plant communities. The physiology of the plant species themselves portends the climate, and the organic material so trapped is amenable to ${ }^{14} \mathrm{C}$-dating enabling chronological assessments of climatic and plant community change (Betancourt et al., 1990). These investigations have revealed that during the late-Pleistocene and early Holocene (12 kya-present), areas within what are now the Chihuahuan and Sonoran deserts of the southwestern United States and northern Mexico, often contained large areas dominated by pygmy conifer forest, a plant community containing important food plants of black bears, including those that produce hard mast such as piñon pine (Pinus spp.), juniper (Juniperusspp.), and oak (Quercus spp.; Betancourt et al., 1990, Chp. 21; Holmgren, Betancourt, \& Rylander, 2006; McAuliffe \& Van Devender, 1998; Onorato, Hellgren, Mitchell, \& Skiles, 2003). Conversely, areas farther north, in northern Arizona and 
New Mexico and southern Colorado and Utah, often contained less hospitable habitat including montane glaciers, tundra and taiga as well as forests dominated by yellow pine (Pinus spp.), limber pine ( $P$. flexilis ), and lodgepole pine ( $P$. contorta ). These regions currently harbor more contiguous black bear habitat. As the Holocene aridified, the habitat conditions bears prefer either shifted up in elevation, such as in the Madrean Sky Islands along the U.S.-Mexico border, or farther north in latitude, and the bears likely followed suit. Thus, vicariant events, namely climatic change that drove the distribution of important food plants for this forest-adapted species, may have influenced the distribution of black bears. This pattern of vicariance and migration may be visible in the phylogeographic pattern of contemporary black bear populations.

Anthropogenic activities, in particular, overharvest, urbanization, and transportation infrastructure such as highways with high traffic volume, have also influenced the abundance, movement patterns, and genetic structure of black bears. In eastern portions of their range, overhunting and persecution during European settlement severely reduced the abundance of black bears which could have rendered these small, isolated populations more susceptible to genetic drift, eroding genetic diversity (Hooker, Laufenberg, Ashley, Sylvest, \& Chamberlain, 2015; Murphy et al., 2018, 2017). In Florida, major roads have heightened mortality (McCown, Kubilis, Eason, \& Scheick, 2009) and acted as semipermeable barriers, that when coupled with urbanization, fragmented bear habitat, decreased connectivity, and caused appreciable genetic structure among subpopulations (Dixon et al., 2007; Karelus et al., 2017). In the Lower Mississippi Alluvial Valley of Louisiana, human-caused mortality combined with extensive habitat loss and fragmentation forced black bears into a patchwork of small populations isolated by anthropogenic activities; active translocations are underway to help restore bear populations there (Murphy et al., 2018). In several states, roads have been shown to influence movements and patterns of habitat selection, as bears either avoid roads or select areas farther from roads, and in some regions, roads created genetic substructure by acting as filters to bear movement (Cushman \& Lewis, 2010; Dixon et al., 2007; Gould, Gould, Cain, \& Roemer, 2019; Hiller, Belant, Beringer, \& Tyre, 2015; Short Bull et al., 2011, 2011).

In the Southwest, limited geographic and genetic sampling has obscured the influence of prehistoric and contemporary ecological processes that shape genetic structure and govern gene flow of black bear populations. Our aim was to fill a crucial gap regarding large-scale population genetic structure of the American black bear by using a suite of microsatellite DNA loci to characterize the genetic profile of 550 individual bears sampled across the Southwest. We focused on two hypotheses. First, we hypothesized that the current genetic structure could be a consequence of Pleistocene-Holocene vicariance whereby bears occupied forest refugia during the LGM, but then followed changes in the distribution of forests as the Holocene dried and warmed (Pleistocene-Holocene Vicariance Hypothesis). If true, we predicted that bears occupying contiguous forests should be relatively closely related and exhibit little genetic substructure. Bears in the Madrean Sky Islands should be more genetically structured (Atwood et al., 2011; Varas-Nelson, 2010) and should show evidence of gene flow characterized by isolation by resistance. Finally, there should be a pronounced asymmetric pattern of gene flow from south to north. Second, we hypothesize that the genetic substructure of bears is dominated by anthropogenic activities typifying the Anthropocene. If true, we predicted that the influence of major highways would be manifested by bears being more closely related on the same side of a highway and more distantly related on opposite sides. This should occur irrespective of the intervening habitat matrix. Although highways may not be barriers, they should act as semipermeable filters that influence gene flow (Anthropocene Filter Hypothesis). Expectations from these hypotheses may not be mutually exclusive, but we envision that the strength of evidence gathered through our analysis will expose their relative importance and that the insight gained will illuminate the processes that helped shape the phylogeography of black bears in North America. Our findings will also aid in the conservation and management of black bears across the Southwest by identifying genetically isolated populations and the landscape features promoting or inhibiting genetic connectivity among black bear populations. 


\section{2| MATERIALS AND METHODS}

\section{1 | Study area}

We conducted our study in the southwestern U.S. (Arizona, Colorado, New Mexico, Texas, and Utah) and northern Coahuila de Zaragoza, Mexico (Figure 1). Orography and climate vary drastically throughout the Southwest with elevation ranging from $21 \mathrm{~m}$ at the Colorado River, AZ to 4,155 m at West Spanish Peak, CO. The desert and grassland communities receive the majority of the 100 to $300 \mathrm{~mm}$ of annual precipitation during the July to October monsoon season with mean monthly maximum temperatures for July from 1961 to 1990 ranging from $~ 16$ to $40^{\circ} \mathrm{C}$ (Davey, Redmond, \& Simeral, 2006, 2007a, 2007b). The forest communities receive the majority of the $\sim 300$ to $1,250 \mathrm{~mm}$ of annual precipitation during the winter with mean monthly minimum temperature for January from 1961 to 1990 ranging from ${ }^{\sim}-20$ to $-4^{\circ} \mathrm{C}$ (Davey et al., 2006, 2007a, 2007b).

Black bears in the Southwest inhabit a mosaic of habitat distributed throughout three ecoregions: Northwestern Forested Mountains, Temperate Sierras, and Southern Semi-Arid Highlands which themselves are often separated by the North American Deserts ecoregion (Omernik \& Griffith, 2014). Biotic communities at higher elevations and latitudes consist of Petran Subalpine and Petran Montane conifer forests transitioning to mid-elevation Great Basin Conifer and Madrean Evergreen woodlands (Brown, 1994). Large expanses of low-elevation valleys are composed of biotic communities such as Plains and Great Basin Grassland, Semidesert Grassland, and the Great Basin, Chihuahuan, and Sonoran desert scrub. These areas comprise a low elevation "sea" that is not typically used by black bears, isolating them on montane 'sky islands' (Brown, 1994; Hellgren, Onorato, \& Skiles, 2005; Olson et al., 2001).

\subsection{Sample and marker selection}

We collected genetic samples from individual black bears through hunter harvest, live-capture, noninvasive genetic sampling, and vehicle collisions. We attempted to sample [?] 25 individuals from each mountain range to obtain an adequate representation of allele frequency and diversity within each assumed subpopulation (Hale, Burg, \& Steeves, 2012). We genotyped all individuals using the ZFX-ZFY sex marker and 15 microsatellite loci (CXX20, G1A, G1D, G10B, G10C, G10H, G10J, G10L, G10M, G10O, G10P, G10U, G10X, MU50, and MU59; Durnin, Palsboll, Ryder, \& McCullough, 2007; Ostrander, Sprague, \& Rine, 1993; Paetkau, Shields, \& Strobeck, 1998; Paetkau \& Strobeck, 1995; Taberlet et al., 1997). Wildlife Genetics International in Nelson, British Columbia, Canada generated all genotypes. Detailed laboratory protocols for microsatellite amplification and error assessment techniques can be found in Paetkau (2003) and Gould et al. (2018).

\subsection{Describing genetic structure and estimating gene flow}

We tested for linkage disequilibrium (LD) using the $\mathrm{r}$ package genepop and null alleles and deviations from Hardy-Weinberg equilibrium (HWE) using the r package popgenreport (version 3.0.0; Adamack \& Gruber, 2014; version 1.0.5; Rousset, Lopez, \& Belkhir, 2017). We conducted a significance test for null alleles by assessing if a bootstrapped $95 \%$ CI for each locus overlapped zero, whereby overlap would indicate that the frequency of null alleles does not differ significantly from zero. We applied a Bonferroni correction ( $\alpha=0.05$ divided by the number of pairwise comparisons for each test) of $\alpha$ [?] 0.0005 (LD) and $\alpha$ [?] 0.003 (HWE) to reduce the likelihood of a false-positive significance test, and we generated allele-frequency statistics for each locus in popgenreport. For each identified subpopulation, we quantified genetic diversity using unadjusted private alleles $\left(A_{P}\right)$ and private alleles using rarefaction $\left(A_{P R}\right)$, which accounts for differences in sample size among subpopulations, using hp-rare v1.0 (Kalinowski, 2004, 2005). We also quantified genetic diversity by estimating expected $\left(\mathrm{H}_{\mathrm{E}}\right)$ and observed $\left(\mathrm{H}_{\mathrm{O}}\right)$ heterozygosity and allelic richness using rarefaction $\left(\mathrm{A}_{\mathrm{R}}\right)$ with the r package diversity (version 1.9.9; Keenan, McGinnity, Cross, Crozier, \& Prodöhl, 2013). We used diversity to calculate an inbreeding coefficient $\left(\mathrm{F}_{\mathrm{IS}}\right)$ and genetic differentiation among subpopulations $\left(\mathrm{F}_{\mathrm{ST}}\right)$ 
along with their $95 \%$ confidence intervals (CI) based on 1,000 bootstrap iterations. We classified values of $\mathrm{F}_{\mathrm{ST}}$ from $0.05-0.14,0.15-0.24$, and [?] 0.25 as moderate, high, and very-high differentiation, respectively, and considered differentiation to be biologically meaningful if the lower CI was [?] 0.05 (Hartl \& Clark, 1997).

We used 2-Bayesian clustering programs to characterize population structure, geneland and structure (Guillot, Estoup, Mortier, \& Cosson, 2005; Pritchard, 2000). Both programs use multi-locus genotypes to infer the number of genetic subpopulations (K) maintaining both Hardy-Weinberg and linkage equilibrium. geneland, however, uses spatial data to infer the spatial boundaries that separate the $\mathrm{K}$ subpopulations (Guillot et al., 2005). Because geneland has been shown to outperform other Bayesian clustering methods in detecting barriers to dispersal in fewer generations for species with higher dispersal abilities (Blair et al., 2012; Safner, Miller, McRae, Fortin, \& Manel, 2011), we based our inferences on geneland. Results from the structure analysis were similar and are available, along with the methods, in Appendix A. We performed 10 independent runs using the uncorrelated and correlated allele frequency models. We varied $\mathrm{K}$ from 1 to 31 (the maximum number of sampling locations +1 ) and then used the model with the highest mean posterior probability to select $\mathrm{K}$ and assign individuals to a cluster. We optimized all models using 500,000 Markov Chain Monte Carlo iterations, 1,000 burn in, a 100-iteration thinning interval, an uncertainty of $2 \mathrm{~km}$ for GPS coordinates, and a maximum rate of 1,650 nuclei for the Poisson-Voronoi tessellation (three times the number of individuals). We implemented our analysis in the $\mathrm{r}$ package geneland using program $\mathrm{r}$ (version 3.4.4; R Core Team, 2018; The Geneland Development Group, 2018). After assessing population structure, we again assessed for linkage disequilibrium, null alleles, and deviations from HWE, and if these tests failed then we reassessed for population structure until tests were not significant.

\subsection{1 | Overview of assessing landscape features influencing gene flow}

We hypothesized that genetic patterns are dictated by geographic distance and that environmental (Pleistocene-Holocene Vicariance Hypothesis) and anthropogenic (Anthropocene Filter Hypothesis) variables would promote or impede bear movement. Female black bears show a relatively high degree of philopatry (Pelletier et al., 2017, 2011; Rogers, 1987) so geographic distance would be expected to influence genetic structure. We created resistance surfaces from a suite of environmental characteristics to model the effects of the environment. We estimated bear movements using random-walk commute times, and then used these paths through the resistance surfaces to calculate effective landscape distances among black bears. We then used a linear mixed-effects model with the effective landscape distance as a predictor of pairwise-genetic distance. We assessed the relative support among resistance surfaces using model selection, and we used the top-ranked model to represent the landscape features that promoted or impeded gene flow and best explained the observed genetic relationships.

\subsubsection{Environmental variables}

Available food resources should influence habitat selection, as black bears must accumulate large-fat stores for both hibernation and reproduction (Costello et al., 2003) and food for bears in arid environments is tied to precipitation (precip; Zlotin \& Parmenter, 2008). Black bears are forest obligates and have evolved morphological and behavioral adaptations associated with exploiting forest stands (Herrero, 1972) and they require thermal refugia (Lara-Diaz, Coronel-Arellano, Lopez-Gonzalez, Sanchez-Rojas, \& Martinez-Gomez, 2018) because they are susceptible to hyperthermia (Sawaya, Ramsey, \& Ramsey, 2017). We modeled these features using canopy height (canopy) and water bodies (water) as the former would provide cover and the latter water for thermoregulation, especially if bears crossed more inhospitable land cover such as desert. Male black bears have been shown to use less rugged areas (Costello, 2010; Johnson et al., 2015; Onorato, Hellgren, Van Den Bussche, \& Skiles, Jr., 2004), so we used a Terrain Ruggedness Index (TRI) to represent potential movement corridors. Linear-water features (streams) contain food, escape and thermal cover, and are travel corridors (Atwood et al., 2011; Johnson et al., 2015). Roads can elicit negative behavioral and genetic effects and can influence bear distribution (Dixon et al., 2007; Gould et al., 2019), so we assessed their effect by estimating road density (rd.density), and interstates and highways (rd.major), which if not 
acting as a barrier, may still inhibit gene flow by heightening mortality rates (Little, Hammond, Martin, Johannsen, \& Miller, 2017).

We determined the spatial extent of the environmental variables, and thus, the subsequent resistance surfaces, by buffering all sample locations by $61 \mathrm{~km}$ based on the maximum-dispersal distance for black bears in the Sangre de Cristo and Mogollon mountains, NM (Costello, 2010). We calculated mean-summer precipitation (Apr-Sep; continuous covariate), using WorldClim2 monthly precipitation levels from 1970-2000 (http://worldclim.org/version2; Fick \& Hijmans, 2017). We obtained canopy height (continuous covariate) at a $1 \mathrm{~km}$ resolution using the National Aeronautics and Space Administration EARTHDATA Spatial Data Access Tool (https://daac.ornl.gov). We obtained location data for streams (binary covariate) and water bodies (binary covariate) from the National Hydrography Dataset (https://www.usgs.gov/core-sciencesystems/ngp/national-hydrography). We derived TRI (continuous covariate) using a National Elevation Dataset $30 \mathrm{~m}$ digital elevation model (www.nationalmap.gov) and the Benthic Terrain Modeler in ArcMap. We calculated road density (continuous covariate) and major roads (categorical covariate) using Open Street Map data (www.openstreetmap.org). For major roads, we used three classifications: interstate highways, state highways, and county roads. We resampled each resistance layer to a $5 \mathrm{~km}$ resolution using bilinear interpolation to reduce the computational intensity of the optimization process given the large extent of the study area without sacrificing an accurate characterization of the landscape (McRae, Dickson, Keitt, \& Shah, 2008). We created and manipulated all resistance surfaces using ArcMap v10.4.1 (Environmental Systems Research Institute, Redlands, CA, USA). We found no correlation among covariates using a Pearson's correlation coefficient of $r$ [?] $|0.60|$.

\subsection{3 | Generating the resistance surface}

We used the $\mathrm{r}$ package resistancega to optimize resistance surfaces, assess the effect of pairwise-effective distance on pairwise-genetic distance, and conduct model selection while accounting for non-independence among the pairwise data (version 4.1-0.2.1; Peterman, 2018; Peterman, Connette, Semlitsch, \& Eggert, 2014). resistancega optimizes resistance surfaces using a genetic algorithm (a process based on the theory of natural selection) that eliminates the subjective assignment of resistance values by expert opinion and the limited exploration of the optimized parameter space (Peterman, 2018; Peterman et al., 2014). The optimization process begins with the selection of parameter values that control the transformation, shape of the transformation, and resistance value for a continuous surface, or if a categorical surface, the assignment of values to each resistance level. After each iteration, pairwise effective distances among all individuals are calculated and a linear mixed-effects model is then fit to the data where effective distance is used to predict genetic distance among individuals (Clarke, Rothery, \& Raybould, 2002; Peterman, 2018; Peterman et al., 2014). The relative support for the combination of parameter values at each iteration is assessed using an objective function from the mixed-effects model, and once the objective function can no longer be improved, surface optimization is completed.

We quantified effective landscape distance using random-walk commute times in the $\mathrm{r}$ package gdistance (version 1.2-2; Van Etten, 2017). We quantified pairwise-genetic distance using the individual based metric proportion of shared alleles $\left(\mathrm{D}_{\mathrm{ps}}\right)$ in the $\mathrm{r}$ package adegenet (version 2.1.1; Jombart, 2008). We applied a monomolecular and Ricker transformation along with their inverse, reverse, and inverse-reverse forms to each continuous-resistance covariate to explore the functional relationship between each covariate and resistance to movement. We constructed our model using a maximum of three covariates due to computational intensity and assessed the relative support among resistance surface models using Akaike's Information Criterion adjusted for small sample size (AICc) with models $>2$ AICc units from the top model being discounted (Burnham \& Anderson, 2002; Hurvich \& Tsai, 1989) and by calculating the model weight $\left(w_{i}\right)$. We conducted the genetic analyses in program $\mathrm{r}$ (version 3.5.2; R Core Team, 2018) and the optimization process with version 3.4.2 (R Core Team, 2017) using the Bridges high performance computing system at the Pittsburgh Supercomputing Center (Nystrom, Levine, Roskies, \& Scott, 2015; Towns et al., 2014).

To explore how geographic distance vs. landscape distance affects pairwise-genetic distance, we used AIC $_{C}$ 
to rank the fit of linear mixed-effects models using Euclidean distance, the top-ranked resistance surface, and to a model that combined them both.

\subsubsection{Relative degree and direction of gene flow}

We investigated asymmetric gene flow by estimating relative migration among the estimated subpopulations using the divMigrate function in the $\mathrm{r}$ package diversity where maximum relative gene flow is set at 1 and minimum at 0 (Keenan et al., 2013; Sundqvist, Keenan, Zackrisson, Prodohl, \& Kleinhans, 2016). We calculated $\mathrm{G}_{\mathrm{ST}}$, an analog of $\mathrm{F}_{\mathrm{ST}}$, for network plots, conducted 1,000 bootstrap iterations to generate $95 \%$ CIs to evaluate if asymmetric gene flow was significant, and chose to display connections [?] 0.50.

\section{3 | RESULTS}

\section{1 | Describing genetic structure}

We genotyped 550 (285M:265F) individuals from 28 localities (Appendix Table B.1). We found a moderate percentage of null alleles (4-12\%) across all loci in this total sample (Appendix Table B.2). We found $82 \%$ of the pairwise comparisons among loci $(n=105)$ for LD to be significant $(P<0.0005$ after Bonferroni correction) and all loci were out of HWE $(P<0.003$ after Bonferroni correction; Appendix Tables B.3-B.4). These metrics suggest that genetic structuring may occur among black bears across the Southwest.

The uncorrelated allele frequency model in geneland identified 6-regional genetic clusters: Boulder Mountain, Utah (BM), the eastern Colorado Plateau and Southern Rocky Mountains (ECPSRM), the Datil-Mogollon Section (DMS), the Mexican Highland and Sacramento sections (MHSS), the Sky Islands south of Interstate 10 (SIS), and the Trans-Pecos region (TP; Figure 1). The presence of null alleles was suggested at loci CXX20 (BM), G10H (ECPSRM), G10J (SIS and TP), G10O (MHSS and SIS), and MU50 (BM and DMS; Appendix Table C.1). We found the CXX20 locus to be non-randomly associated with G10B and G10H in the BM subpopulation (Appendix Tables C.2-C.4). The G10U and G10L loci were out of HW proportions in the ECPSRM and DMS, respectively (Appendix Table C.5). The presence of null alleles suggests these loci may not accurately represent genetic structure and diversity while the presence of linkage disequilibrium and deviations from HW proportions suggests there could be additional genetic structure that what was not detected under the uncorrelated allele frequency model.

Allelic richness was lowest in the SIS $\left(A_{R}=3.91\right)$ and highest in the DMS $\left(A_{R}=5.43\right)$; the TP had the second highest allelic richness despite small sample size (Table 1 ). The number of private alleles using rarefaction was lowest in DMS $\left(\mathrm{A}_{\mathrm{PR}}=0.09\right)$ and highest in the TP $\left(\mathrm{A}_{\mathrm{PR}}=1.79\right.$; Table 1; Appendix Table C.6). Observed heterozygosity ranged from $0.42-0.64$ and was slightly lower than $\mathrm{H}_{\mathrm{E}}(0.44-0.62)$ for all regional subpopulations except for the TP (Table 1). The $\mathrm{F}_{\text {IS }}$ estimates suggested potential inbreeding within the ECPSRM and DMS subpopulations, but along with $\mathrm{H}_{\mathrm{O}}$ being lower than $\mathrm{H}_{\mathrm{E}}$ for both subpopulations, it is more likely that a Wahlund effect, rather than inbreeding, is occurring, which indicates greater substructure within these two regions (Wahlund, 1928). Genetic differentiation was the lowest between the ECPSRM and DMS $\left(\mathrm{F}_{\mathrm{ST}}=0.03\right)$ and highest between the TP and SIS $\left(\mathrm{F}_{\mathrm{ST}}=0.44\right)$. Overall, the two most isolated subpopulations, BM and the TP, displayed the highest levels of genetic differentiation compared to all other subpopulations (Table 2).

The correlated allele frequency model identified 14-genetic clusters that closely tracked the sampled mountain ranges. The $\mathrm{BM}$ and $\mathrm{TP}$ subpopulations from the regional results remained while the larger clusters were broken down into 12 subpopulations (Figure 1). We did not find evidence of null alleles (Appendix Table D.1-D.8). All loci within each respective subpopulation were in HWE (Appendix Table D.9). Because there was no discernable pattern of null alleles, LD, or HW disequilibrium for [?] 1 locus at [?] 1 subpopulation we retained all loci in our analyses (Morin et al., 2010).

The TP subpopulation retained the highest number of private alleles $\left(\mathrm{A}_{\mathrm{PR}}=1.39\right)$ while the Mogollon Rim $(\mathrm{MR})$ was estimated to have the least number of private alleles $\left(\mathrm{A}_{\mathrm{PR}}=0.01\right.$; Table 1$)$. The Chiricahua 
complex (CHC) and the Huachuca-Santa Rita mountains (HSRM) subpopulations both exhibited a fixed allele (122 bp) at the MU50 locus (Appendix Table D.10), these two subpopulations are south of Interstate 10. Heterozygosity was lowest in the HRSM and highest in the TP (Table 1). The $\mathrm{F}_{\text {IS }}$ estimates did not suggest inbreeding (Table 1). Pairwise differentiation was high or very-high when subpopulations were compared to the BM, HSRM, and TP subpopulations ( $\mathrm{F}_{\mathrm{ST}}$ [?] 0.15; Table 3), this was not unexpected as both the BM and TP populations are isolated from the other populations. The La Sal Mountains (LSM), another somewhat isolated subpopulation along the Utah-Colorado border, was moderately differentiated from all other subpopulations except for three subpopulations to the south: the large Sangre de Cristo Mountains (SCM), which was geographically close, and the San Juan and Chuska mountains (SJC) and Zuni Mountains (ZM; Table 3). Genetic differentiation was low to moderate among the remaining subpopulations (Table 3).

\section{2 | Landscape features regulating gene flow}

The top-ranked resistance-surface model was well supported $\left(w_{i}=1.00\right)$, substantially outperformed the second-ranked model $\left(\Delta \mathrm{AIC}_{\mathrm{c}}=47.18\right)$, and included canopy, precipitation, and TRI (Appendix Tables E.1 and E.2). The transformations that best represented the relationship between canopy, precipitation, and TRI with resistance to movement were the inverse monomolecular, inverse Ricker, and monomolecular, respectively, indicating that resistance decreased as canopy increased, decreased as precipitation increased until the covariate reached moderate levels at which point resistance started to increase, and increased as TRI increased (Table 4). Precipitation contributed the most to the top-ranked resistance surface (58\%) followed by canopy (40\%) with a small contribution from TRI $(2 \%)$. This top-ranked model received considerable support when compared to Euclidean distance alone, suggesting isolation by resistance better explained the observed-genetic pattern than isolation by distance (Table 4). A model composed of both effective and Euclidean distance, however, outperformed $\left(w_{i}=1.00\right)$ the top-ranked resistance model suggesting isolation by distance is still an important component explaining genetic distance (Table 4). Our analysis did not show support for any resistance-based models that included road density or major roads (Appendix Tables E.1 and E.2).

\section{3 | Relative degree and direction of genetic connectivity}

The directional relative migration network clustered populations in the northern part of our study region along the Colorado-New Mexico border (ECPSRM) with populations located in the central portions of our study region, in the states of Arizona and New Mexico (DMS and MHSS) suggesting high rates of gene flow among these regional subpopulations. Estimated gene flow among the remaining subpopulations was low as most of the pairwise-relative migration values $(87 \%)$ were half of that occurring between the highest relative gene flow from central Arizona and western New Mexico (DMS) to the Colorado-New Mexico border (ECPSRM; Figure 2; Appendix Figure C.1; Appendix Table C.7). There was a pronounced south-tonorth linkage pattern of asymmetric gene flow from central Arizona and western New Mexico (DMS) to the Colorado-New Mexico border (ECPSRM) and central New Mexico (MHSS), from southern Arizona (SIS) to central New Mexico (MHSS), and from Texas and northern Mexico (TP) to the Colorado-New Mexico border (ECPSRM; Figure 2; Appendix Figure C.1; Appendix Table C.7). The mountain range subpopulations exhibited a similar pattern with subpopulations from the central portion of the study area clustering together and asymmetric gene flow in a northward direction (Figures 1 and 3; Appendix Figure D.1; Appendix Table D.11).

\section{4 | DISCUSSION}

Black bears are omnivorous, but vegetation, fruits and nuts comprise 70-90\% of the diet, supplemented with insects and vertebrates (Delgadillo Villalobos, Isern, Garcia Aranda, \& Rincon, 2019). In spring, in the higher elevations and after emergence from hibernation, they feed on grasses and other vegetation, in mid-late summer on soft mast, such as berries, and in late summer-fall prior to hibernation they forage on 
hard mast, such as acorns and piñon pine nuts (Beck, 1991; Costello et al., 2001; Onorato et al., 2003). In lower elevations within the Southwest, they also feed on sotol, yucca, and prickly pear cactus (Delgadillo Villalobos et al., 2019). Although found in semiarid shrublands, black bears are primarily a forest-adapted species and forests are important habitats across their range (Evans, Rittenhouse, Hawley, \& Rego, 2017; Gould et al., 2019; Onorato et al., 2003). Thus, it stands to reason that individual black bears would track the abundance of energy-rich foods critical to their reproductive success and survival during hibernation over the short term, which would explain contemporary movements and dispersal patterns (Costello et al., 2003; Hellgren et al., 2005), and populations would track the distribution of their primary habitat over the long term, which would explain species distribution and population genetic structure.

During the Pleistocene and Holocene, paleoecological reconstruction reveals considerable forest habitat available to black bears throughout the Southwest. This forest, dominated by different species of piñon pine, juniper, and oak depending on time and location, was widespread, and found throughout lower elevation areas in current Chihuahuan and Sonoran deserts. In certain areas, these forested habitats were stable for 10,000-20,000 years, and were often found at lower elevations (e.g., as much as a 1,000 m lower depending on species) than they are today (Holmgren et al., 2006; McAuliffe \& Van Devender, 1998; Van Devender, 1990a, 1990b). As climates aridified, forest habitats either moved up in elevation, moved north, dependent upon precipitation patterns, soil moisture regimes, and winter temperatures, or both. The Southwest was most likely a refugium for black bears during various periods in the Pleistocene and Holocene when habitats in more northerly latitudes also were dominated by more cold-adapted plant species that black bears do not typically use (Betancourt et al., 1990).

Additional independent evidence supports the hypothesis that the Southwest was a refugium for black bears during the LGM and that bears were isolated into one or more refugia. In the Southwest, evidence of these expansion and isolation events can be found in the fossil record. Fossil specimens identified as modern day black bear have been discovered at 12 relatively low-elevation Pleistocene sites (mean $=1,495 \mathrm{~m}$; range $=1,171-1,716 \mathrm{~m})$ dated to the mid- and late-Wisconsin age ( $11,000-65,000 \mathrm{BP})$ within the present day Chihuahuan and Sonoran deserts (Harris, 1987, 1989, 1993, 2003; Messing, 1986; Saunders, 1977; Skinner, 1942; Slaughter, 1975). Thus, for much of the late-Pleistocene and into the early-Holocene, the dominant paleovegetation community of the region was a piñon-juniper-oak woodland that black bears inhabited, similar to the plant community selected by black bears in the Sky Islands today (Onorato et al., 2003). The isolated Sky Island mountain ranges, currently inhabited by black bears, were also functionally connected by this piñon-juniper-oak woodland (Van Devender, 1990a).

Our study further supports the hypothesis that the Southwest served as a fourth Pleistocene refugium for the black bear during the LGM and that their present-day genetic structure is most likely a result of vicariant events as habitat fragmentation occurred when glaciers receded post-LGM. Our sampled populations were highly structured with those from central Arizona, central New Mexico, and southern Colorado clustering together; these populations were distinct but related to populations within the Sky Islands border region and all these populations were distinct from two isolated populations, one in Utah and another in the Trans-Pecos region of west Texas and northern Mexico. Populations would be expected to show genetic structure if repeated episodes of isolation and admixture occurred, driven by changes in habitat distribution. Further, the Trans-Pecos population likely originated from the Sierra Madre Oriental (Onorato, Hellgren, Van Den Bussche, \& Doan-Crider, 2004), whereas, the other more westerly populations would have likely arisen from the Sierra Madre Occidental (Varas-Nelson, 2010). This phylogeographic structure is consistent with a Pleistocene-Holocene Vicariance Hypothesis.

\subsection{The scale of population genetic structure in Southwestern black bear po- pulations}

Regionally, subpopulation boundaries followed the distribution of three major ecoregions (Omernik \& Griffith, 2014): the Northwestern Forested Mountains contained populations in the Eastern Colorado Plateau and Southern Rocky Mountains (ECPSRM) and Boulder Mountain, Utah (BM); the Temperate Sierras harbored 
bears from the Datil-Mogollon Section (DMS) and the Mexican Highlands and Sacramento Section (MHSS); and the Southern Semi-Arid Highlands contained populations from the Sky Islands South of Interstate 10 (SIS). Low genetic differentiation and relatively high gene flow among the three largest subpopulations suggests these subpopulations (ECPSRM, DMS, and MHSS) form the core contemporary Southwest black bear population. The SIS in southern Arizona shows moderate differentiation from this core population, which is surprising given their proximity (distance between the SIS and the DMS is $\sim 20 \mathrm{~km}$ ) and is likely due to the relatively inhospitable habitat matrix separating the Sky Islands region from other subpopulations. The Sky Islands are a series of 'montane islands separated by a desert sea' presenting as a complete or semi-permeable barrier to black bear dispersal and gene flow as the intervening landscape matrix of primarily desert and grassland within the Chihuahuan and Sonoran desert biomes (Lomolino et al., 1989). Atwood et al. (2011) also found genetic substructure among black bear populations along the U.S.-Mexico border within the Sky Islands region.

There was a relatively high degree of genetic differentiation when comparing Boulder Mountain, Utah and the Trans-Pecos region in west Texas and northeast Mexico to the other Southwest subpopulations. We believe this differentiation is due to genetic isolation rather than incomplete sampling. The origination of the Boulder Mountain population is more enigmatic and more information is needed to determine if it is a product of eastward expansion by populations from the Pacific Northwest refugium or through the expansion and isolation of populations from the north (Lackey, Beckmann, \& Sedinger, 2013; Malaney, Lackey, Beckmann, \& Matocq, 2018; Puckett et al., 2015). We had a small sample from the Trans-Pecos region, but that subpopulation had the highest allelic richness, the highest observed heterozygosity, a large number of private alleles, and some private alleles occurred at high frequency, indicating a period of isolation and genetic differentiation followed by little connectivity (Slatkin, 1985). The existence of private alleles in the Trans-Pecos region is likely a product of bears recolonizing west Texas from the Sierra Madre Oriental (Onorato, Hellgren, Van Den Bussche, \& Doan-Crider, 2004; Onorato et al., 2007), which were distinct from bears in the Sierra Madre Occidental (Varas-Nelson, 2010). While the high levels of genetic diversity may partly be a product of migration-dispersal events due to hard mast crop failure in Big Bend National Park that resulted in movements of bears back to the Sierra del Carmen, Mexico and invariably subsequent movements back to west Texas (Onorato et al., 2003; Onorato, Hellgren, Van Den Bussche, \& Doan-Crider, 2004). This unique genetic variation also reflects the ancestral relationship between the eastern Mexican and eastern American black bear populations that are hypothesized to have occupied the American Southeast refugium before diverging 67-31 kya (Pedersen et al., 2021). Pedersen et al.'s (2021) hypothesis that gene flow between black bear populations in the Sierra Madre Occidental and Oriental was inhibited by the Chihuahuan Desert conflicts with paleomidden evidence that shows pygmy conifer woodlands dominated the present-day Chihuahuan Desert during the Pleistocene (Betancourt et al., 1990). Furthermore, black bear fossils have been discovered at low-elevation Pleistocene caves dated to 11,000-65,000 BP within the presentday Chihuahuan Desert (Harris, 1987, 1989, 1993, 2003; Messing, 1986; Saunders, 1977; Slaughter, 1975). Thus, we suggest that these caves be sampled for ancient environmental DNA to further our understanding of the refugia and subsequent movements of bears in the American Southwest and northern Mexico along with the working model of American black bear phylogeography.

In conclusion, the population genetic structure of black bears across southwestern North America appears to bear the signature of repeated isolation and admixture events as black bear populations were isolated into refugia over a long enough period of time for unique genetic variation to accumulate and then populations expanded and admixed as the distribution of forest land cover changed following glacial recession (Puckett et al., 2015; Varas-Nelson, 2010).

\subsection{The influence of landscape resistance and geographic distance on gene flow}

Our estimates of the relative degree and direction of gene flow also suggested that gene flow occurred from south to north, was high among the regionally central subpopulations where contiguous forest existed, limited between these central subpopulations and the southern Madrean Sky Island Archipelago, where gene flow 
appeared to be filtered by the mosaic of less hospitable habitat found in the lowlands, and was affected by geographic distance. The Boulder Mountain population, Utah (BM) and the Trans-Pecos population in west Texas and northeast Mexico (TP) were isolated from the other populations and showed little gene flow with them. This pattern was not unexpected as $\sim 200 \mathrm{~km}$ of the Colorado Plateau and $\sim 430 \mathrm{~km}$ of the Chihuahuan Desert separates the BM and TP populations from their nearest subpopulation, respectively.

The consistent, unidirectional pattern of asymmetric gene flow northward is indicative of prehistoric range expansion. Varas-Nelson (2010) noted a similar pattern in northern Mexico where the migration rate from Sierra El Nido in Sonora to Sierra San Luis in Chihuahua, ${ }^{\sim} 250 \mathrm{~km}$ to the north, was $2.5 \mathrm{x}$ greater than the migration rate southward. Northward expansion also supports previous research that postulated that the Southwest refugium dominated the genetic assemblage of the Intermountain West before admixing along the U.S.-Canada border with bears that originated from the Great Lakes region (Pelletier et al., 2011; Puckett et al., 2015).

Our resistance-based models of gene flow revealed that areas with higher canopy cover and precipitation, essentially forested habitats, predicted high gene flow and within these areas, gene flow was facilitated by less rugged areas. Gene flow was also affected by geographic distance. Thus, populations connected by contiguous forest had high gene flow, populations separated by desert and isolated by distance had lower gene flow. Because female black bears are highly philopatric, the effect of distance on gene flow may be governed by their behavior, but also mediated by long-distance dispersal events by male bears with male bears also having been shown to select against ruggedness (Apps, McLellan, \& Woods, 2006; Johnson et al., 2015; Lara-Díaz et al., 2018; Pelletier et al., 2011). So, it appears that habitat most likely acts as a conduit (e.g., forest) or filter (e.g., desert) to bear movement and that geographic distance plays an important role owing to intersexual differences in movement behavior.

\subsection{The influence of transportation infrastructure on genetic structure and gene flow}

Our analyses did not support the hypothesis that interstate highways are acting to limit the movement of black bears across the Southwest (Anthropocene Filter Hypothesis). The uncorrelated allele frequency model failed to detect such a genetic pattern at the regional level and the correlated frequency model often clustered bears together that were on opposite sides of major interstates. For example, bears from the Mogollon Rim (MR) population in Arizona were found on both sides of Interstates 17 and 40; bears from the Zuni Mountains (ZM) population in New Mexico also clustered together from both sides of Interstate 25 and 40; bears from the Sandia and Manzano mountains (SMM) population in New Mexico were found on both sides of Interstate 40; bears from the Gila complex (GC) in New Mexico were found on both sides of Interstate 25, although primarily to the west; and bear populations from the Sky Islands North of Interstate 10 (SIN) and from the Chiricahua complex (CHC) of Arizona were found on both sides of Interstate 10.

Roads, urbanization and interstate highways can negatively influence carnivore populations and the size of the interstate and relative traffic flow may be contributing factors as well (Riley et al., 2014; Serieys, Lea, Pollinger, Riley, \& Wayne, 2015). Perhaps one of the most extreme cases has occurred in the Santa Monica Mountains of southern California where the morass of urbanization and grand thoroughfares has restricted population size and caused degradation in genetic variation in mountain lions (Puma concolor) and has even caused aberrant behaviors to arise such as when an adult male lion killed his own offspring (Riley et al., 2014). Although bear resource use is negatively affected by roads (Gould et al., 2019), the effect of roads on bear movements and gene flow varies across their range. Roads had little effect on movements in remote areas such as in Idaho (Cushman, McKelvey, Hayden, \& Schwartz, 2006) but have had major impacts on movement patterns and genetic structure in more heavily urbanized areas such as Florida (Dixon et al., 2007; McCown et al., 2009). The highways in the Southwest receive less traffic volume than heavily populated areas like California or Florida, so their impedance to bear movement would be expected to be reduced. Furthermore, black bears have a relatively long generation time and interstate highways are recent, anthropogenic barriers or filters, and their current genetic structure may not reflect the impact of interstate 
highways as there has been insufficient time for populations to diverge among those bisected by interstates (Blair et al., 2012; Epps et al., 2005; Safner et al., 2011).

A handful of observed long-distance and cross-interstate movements by bears supports the hypothesis that interstates in the Southwest are not yet a barrier to bear movement and thus have most likely not influenced gene flow. We genotyped a male bear that was first detected using noninvasive genetic sampling by the Colorado Parks and Wildlife in the Sangre de Cristo Mountains, Colorado that died from a vehicle collision $\sim 360 \mathrm{~km}$ to the southwest on Interstate 40 between the Zuni Mountains and Mt. Taylor, New Mexico. A female bear detected in the Sangre de Cristo Mountains, New Mexico was also detected south of Interstate 25, $90 \mathrm{~km}$ away in the Sandia Mountains, and a male bear detected in the Sacramento Mountains was assigned to the Gila complex but was captured and radio-collared on White Sands Missile Range in the San Andres Mountains. The Gila complex is $\sim 150 \mathrm{~km}$ to the west of the Sacramento Mountains and the San Andres Mountains is $\sim 100 \mathrm{~km}$ to the west and lies between the Sacramento Mountains and the Gila complex. These observations suggest that this bear was dispersing from the Gila complex to the Sacramento Mountains and most likely crossed Interstate 25 and State Highway 70. We assigned two bears, a male and a female, to the Zuni Mountains south of Interstate 40 that the NMDGF collected via hunter harvest and depredation, respectively, north of the interstate in the Sangre de Cristo Mountains, New Mexico, a straight-line distance of $\sim 300 \mathrm{~km}$. Finally, Liley and Walker (2015) placed a GPS collar on a male bear on the New Mexico-Colorado border that subsequently traveled to central Colorado and crossed Interstate 25 twice before returning to New Mexico, a cumulative distance of $1,482 \mathrm{~km}$. These observations show that bears in the Southwest can travel long distances and cross both highways and interstates when doing so.

\subsection{Conservation Implications}

American black bears in the Southwest occupy a naturally fragmented landscape with low-density subpopulations linked together into a metapopulation (Gould et al., 2018; Onorato, Hellgren, Van Den Bussche, \& Doan-Crider, 2004). Habitat loss and fragmentation owing to climate change, anthropogenic land use, and U.S.-Mexico border security could increase the extinction risk of individual subpopulations and perhaps sever linkages among key subpopulations within the metapopulation (Lara-Díaz et al., 2021).

Climate change is contributing to a rise in aridity and temperature in the Southwest and has led to increases in insect outbreaks, intense droughts, and catastrophic wildfires resulting in substantial tree mortality reducing the distribution and quality of bear habitat over the long term (Gould et al., 2019; Thorne et al., 2018; Williams et al., 2010). Increasing human development and population growth is likely to increase human population density and traffic rates resulting in higher rates of road mortality, lower genetic connectivity, and enhance fragmentation, heightening the extinction risk for some subpopulations (Dixon et al., 2007; Ernest, Vickers, Morrison, Buchalski, \& Boyce, 2014; Riley et al., 2014). Finally, the U.S.-Mexico border wall poses a threat to the persistence of bears in the Southwest. The current border wall spans $~ 1,125 \mathrm{~km}$, and in the recent past, the United States government proposed to increase the length of the border wall and change vehicle barriers that are permeable to bears, to impassable pedestrian barriers that would impede cross-border migration and dispersal (4-10 m tall, 5-10 cm wide gaps; Flesch et al., 2010). The current wall and more impenetrable barriers could sever linkages between populations in the Sierra Madre Occidental of northern Mexico with those in southern Arizona and New Mexico (Atwood et al., 2011; Varas-Nelson, 2010) and the Sierra Madre Oriental of northern Mexico with those in west Texas (Hellgren et al., 2005; Onorato, Hellgren, Van Den Bussche, \& Doan-Crider, 2004). Binational collaboration between the United States and Mexico could be crucial to the future persistence and viability of the black bear metapopulation in southwestern North America and represents a unique conservation opportunity.

\section{ACKNOWLEDGMENTS}

We thank the Arizona Game and Fish Department (AZGFD), Colorado Parks and Wildlife (CPW), Museum of Southwestern Biology (MSB), New Mexico Department of Game and Fish (NMDGF), Utah Division of 
Wildlife Resources, and While Sands Missile Range (WSMR) for providing genetic samples. We also thank D. Toups Dugas and S. Trecakov with the New Mexico State University Information and Communication Technologies program for their technical assistance. K. Engebretsen and J. Naranjo with New Mexico State University (NMSU), E. Butler, A. Howard, R. Langley, T. McCall, E. Rubin, and R. Tucker with AZGFD, J. Apker with CPW, Doug Burkett with WSMR, J. Cole with the Navajo Nation Department of Fish and Wildlife, and J. Cook with the MSB provided invaluable in-kind support. Our work was supported by National Science Foundation grant number ACI-1548562. We used the Bridges system as supported by NSF award number ACI-1445606 at the Pittsburgh Supercomputing Center. Comments by W. Gould, T. Wright, and 2 anonymous reviewers improved earlier drafts. The NMDGF, the NMSU Departments of Fish, Wildlife and Conservation Ecology and Biology, The NMSU Agricultural Experiment Station, Vermejo Park Ranch, and T\&E Inc. provided funding. The AZGFD with Wildlife Restoration Act funded the collection of locational data and genetic samples within Arizona. Any use of trade, firm, or product names is for descriptive purposes only and does not imply endorsement by the U.S. Government.

\section{REFERENCES}

Adamack, A. T., \& Gruber, B. (2014). PopGenReport: Simplifying basic population genetic analyses in R. Methods in Ecology and Evolution , 5 (4), 384-387. doi: 10.1111/2041-210X.12158

Apps, C. D., McLellan, B. N., \& Woods, J. G. (2006). Landscape partitioning and spatial inferences of competition between black and grizzly bears. Ecography, 29 (4), 561-572.

Atwood, T. C., Young, J. K., Beckmann, J. P., Breck, S. W., Fike, J., Rhodes, O. E., \& Bristow, K. D. (2011). Modeling connectivity of black bears in a desert sky island archipelago. Biological Conservation , 144 (12), 2851-2862. doi: 10.1016/j.biocon.2011.08.002

Aubry, K. B., Statham, M. J., Sacks, B. N., Perrine, J. D., \& Wisely, S. M. (2009). Phylogeography of the North American red fox: Vicariance in Pleistocene forest refugia. Molecular Ecology , 18 (12), 2668-2686. doi: 10.1111/j.1365-294X.2009.04222.x

Beck, T. D. I. (1991). Black bears of west-central Colorado (p. 86) [Technical Publication No. 39]. Colorado Division of Wildlife.

Betancourt, J. L., Van Devender, T. R., \& Martin, P. S. (1990).Packrat Middens. The Last 40,000 Years of Biotic Change.University of Arizona Press, Tucson.

Blair, C., Weigel, D. E., Balazik, M., Keeley, A. T. H., Walker, F. M., Landguth, E., .. Balkenhol, N. (2012). A simulation-based evaluation of methods for inferring linear barriers to gene flow: Methods for inferring genetic barriers. Molecular Ecology Resources , 12 (5), 822-833. doi: 10.1111/j.1755-0998.2012.03151.x

Brown, D. E. (1994). Biotic communities: Southwestern United States and northwestern Mexico . Salt Lake City, UT, USA: University of Utah Press.

Burnham, K. P., \& Anderson, D. R. (2002). Model selection and multi-model inference: A practical information-theoretic approach (2nd ed.). New York, NY, USA: Springer-Verlag New York.

Clarke, R. T., Rothery, P., \& Raybould, A. F. (2002). Confidence limits for regression relationships between distance matrices: Estimating gene flow with distance. Journal of Agricultural, Biological, and Environmental Statistics , 7 (3), 361. doi: 10.1198/108571102320

Costello, C. M. (2010). Estimates of dispersal and home-range fidelity in American black bears. Journal of Mammalogy , 91 (1), 116-121. doi: 10.1644/09-MAMM-A-015R1.1

Costello, C. M., Jones, D. E., Green Hammond, K. A., Inman, R. M., Inman, K. H., Thompson, B. C., ... Quigley, H. B. (2001). A study of black bear ecology in New Mexico with models for population dynamics and habitat suitability (Final Report No. W-131-R). Santa Fe, New Mexico, USA: New Mexico Department of Game and Fish. 
Costello, C. M., Jones, D. E., Inman, R. M., Inman, K. H., Thompson, B. C., \& Quigley, H. B. (2003). Relationship of variable mast production to American black bear reproductive parameters in New Mexico.Ursus , 14 (1), 1-16. JSTOR. Retrieved from JSTOR.

Cushman, S. A., \& Lewis, J. S. (2010). Movement behavior explains genetic differentiation in American black bears. Landscape Ecology , 25 (10), 1613-1625. doi: 10.1007/s10980-010-9534-6

Cushman, S. A., McKelvey, K. S., Hayden, J., \& Schwartz, M. K. (2006). Gene flow in complex landscapes: Testing multiple hypotheses with causal modeling. The American Naturalist , 168 (4), 486-499. doi: $10.1086 / 506976$

Davey, C. A., Redmond, K. T., \& Simeral, D. B. (2006). Weather and climate inventory, National Park Service, Southern Colorado Plateau Network (Natural Resource Technical Report NPS/SCPN/NRTR No. 2006/007; p. 136). Fort Collins, Colorado: National Park Service.

Davey, C. A., Redmond, K. T., \& Simeral, D. B. (2007a). Weather and climate inventory, National Park Service, Chihuahuan Desert Network (Natural Resource Technical Report NPS/CHDN/NRTR No. 034). Fort Collins, Colorado: National Park Service.

Davey, C. A., Redmond, K. T., \& Simeral, D. B. (2007b). Weather and climate inventory, National Park Service, Sonoran Desert Network(Natural Resource Technical Report NPS/SODN/NRTR No. 2007/044). Fort Collins, Colorado: National Park Service.

Delgadillo Villalobos, J. A., Isern, S. G., Garcia Aranda, M. A., \& Rincon, R. V. (2019). Black bear in Mexico. In Wildlife Ecology and Management in Mexico (pp. 206-221). Texas A\&M University Press, College Station.

Dixon, J. D., Oli, M. K., Wooten, M. C., Eason, T. H., McCown, J. W., \& Cunningham, M. W. (2007). Genetic consequences of habitat fragmentation and loss: The case of the Florida black bear (Ursus americanus floridanus ). Conservation Genetics , 8 (2), 455-464. doi: 10.1007/s10592-006-9184-z

Durnin, M. E., Palsbøll, P. J., Ryder, O. A., \& McCullough, D. R. (2007). A reliable genetic technique for sex determination of giant panda (Ailuropoda melanoleuca) from non-invasively collected hair samples. Conservation Genetics , 8 (3), 715-720. doi: 10.1007/s10592-006-9196-8

Epps, C. W., Palsbøll, P. J., Wehausen, J. D., Roderick, G. K., Ramey, R. R., \& McCullough, D. R. (2005). Highways block gene flow and cause a rapid decline in genetic diversity of desert bighorn sheep: Highways reduce genetic diversity. Ecology Letters , 8 (10), 1029-1038. doi: 10.1111/j.1461-0248.2005.00804.x

Ernest, H. B., Vickers, T. W., Morrison, S. A., Buchalski, M. R., \& Boyce, W. M. (2014). Fractured Genetic Connectivity Threatens a Southern California Puma (Puma concolor) Population. PLOS ONE ,9 (10), e107985. doi: 10.1371/journal.pone.0107985

Evans, M. J., Hawley, J. E., Rego, P. W., \& Rittenhouse, T. A. G. (2014). Exurban land use facilitates human-black bear conflicts. The Journal of Wildlife Management, 78 (8), 1477-1485. doi: 10.1002/jwmg.796

Evans, M. J., Rittenhouse, T. A. G., Hawley, J. E., \& Rego, P. W. (2017). Black bear recolonization patterns in a human-dominated landscape vary based on housing: New insights from spatially explicit density models. Landscape and Urban Planning , 162 , 13-24. doi: 10.1016/j.landurbplan.2017.01.009

Fick, S. E., \& Hijmans, R. J. (2017). WorldClim 2: New 1-km spatial resolution climate surfaces for global land areas. International Journal of Climatology , 37 (12), 4302-4315. doi: 10.1002/joc.5086

Flesch, A. D., Epps, C. W., III, J. W. C., Clark, M., Krausman, P. R., \& Morgart, J. R. (2010). Potential effects of the United States-Mexico border fence on wildlife. Conservation Biology , 24 (1), 171-181. doi: 10.1111/j.1523-1739.2009.01277.x

Gould, M. J., Cain, J. W., Roemer, G. W., Gould, W. R., \& Liley, S. G. (2018). Density of American black bears in New Mexico. The Journal of Wildlife Management, 82 (4), 775-788. doi: 10.1002/jwmg.21432 
Gould, M. J., Gould, W. R., Cain, J. W., \& Roemer, G. W. (2019). Validating the performance of occupancy models for estimating habitat use and predicting the distribution of highly-mobile species: A case study using the American black bear. Biological Conservation, 234 , 28-36. doi: 10.1016/j.biocon.2019.03.010

Guillot, G., Estoup, A., Mortier, F., \& Cosson, J. F. (2005). A spatial statistical model for landscape genetics. Genetics ,170 (3), 1261-1280. doi: 10.1534/genetics.104.033803

Hale, M. L., Burg, T. M., \& Steeves, T. E. (2012). Sampling for microsatellite-based population genetic studies: 25 to 30 individuals per population is enough to accurately estimate allele frequencies.PLoS ONE , 7 (9), e45170. doi: 10.1371/journal.pone.0045170

Harris, A. H. (1987). Reconstruction of Mid Wisconsin Environments in Southern New Mexico. National Geographic Research , 3 (2), 142-151.

Harris, A. H. (1989). The New Mexican Late Wisconsin-East Versus West.National Geographic Research , 5 (2), 205-217.

Harris, A. H. (1993). Quaternary vertebrates of New Mexico. In Vertebrate Paleontology in New Mexico (Vol. 2, pp. 179-197). Bulletin of the New Mexico Museum of Natural History.

Harris, A. H. (2003). The Pleistocene vertebrate fauna from Pendejo Cave. In Pendejo Cave (pp. 36-65). University of New Mexico Press, Albuquerque.

Hartl, D. L., \& Clark, A. G. (1997). Principles of population genetics (3rd ed.). Sinauer Associates, Inc, Sunderland, MA.

Hellgren, E. C., Onorato, D. P., \& Skiles, J. R. (2005). Dynamics of a black bear population within a desert metapopulation. Biological Conservation , 122 (1), 131-140. doi: 10.1016/j.biocon.2004.07.007

Herrero, S. (1972). Aspects of evolution and adaptation in American black bears (Ursus americanus Pallas) and brown and grizzly bears (U. arctos Linné.) of North America. Bears: Their Biology and Management, 2 , 221-231. JSTOR. doi: 10.2307/3872586

Hiller, T. L., Belant, J. L., Beringer, J., \& Tyre, A. J. (2015). Resource selection by recolonizing American black bears in a fragmented forest landscape. Ursus , 26 (2), 116-128. doi: 10.2192/URSUS-D-15-00023.1

Hofreiter, M., \& Stewart, J. (2009). Ecological change, range fluctuations and population dynamics during the Pleistocene.Current Biology , 19 (14), R584-R594. doi: 10.1016/j.cub.2009.06.030

Holmgren, C. A., Betancourt, J. L., \& Rylander, K. A. (2006). A 36,000-yr vegetation history from the Peloncillo Mountains, southeastern Arizona, USA. Palaeogeography, Palaeoclimatology, Palaeoecology ,240 (3), 405-422. doi: 10.1016/j.palaeo.2006.02.017

Hooker, M. J., Laufenberg, J. S., Ashley, A. K., Sylvest, J. T., \& Chamberlain, M. J. (2015). Abundance and density estimation of the American black bear population in central Georgia. Ursus ,26 (2), 107-115. doi: 10.2192/URSUS-D-14-00025

Hurvich, C. M., \& Tsai, C.-L. (1989). Regression and time series model selection in small samples. Biometrika , 76 (2), 297. doi: $10.2307 / 2336663$

Johnson, H. E., Breck, S. W., Baruch-Mordo, S., Lewis, D. L., Lackey, C. W., Wilson, K. R., ... Beckmann, J. P. (2015). Shifting perceptions of risk and reward: Dynamic selection for human development by black bears in the western United States. Biological Conservation ,187, 164-172. doi: 10.1016/j.biocon.2015.04.014

Jombart, T. (2008). adegenet: A R package for the multivariate analysis of genetic markers. Bioinformatics , 24 (11), 1403-1405. doi: 10.1093/bioinformatics/btn129

Kalinowski, S. T. (2004). Counting alleles with rarefaction: Private alleles and hierarchical sampling designs. Conservation Genetics ,5 (4), 539-543. doi: 10.1023/B:COGE.0000041021.91777.1a 
Kalinowski, S. T. (2005). hp-rare 1.0: A computer program for performing rarefaction on measures of allelic richness. Molecular Ecology Notes , 5 (1), 187-189. doi: https://doi.org/10.1111/j.1471-8286.2004.00845.x

Karelus, D. L., McCown, J. W., Scheick, B. K., van de Kerk, M., Bolker, B. M., \& Oli, M. K. (2017). Effects of environmental factors and landscape features on movement patterns of Florida black bears. Journal of Mammalogy , 98 (5), 1463-1478. doi: 10.1093/jmammal/gyx066

Keenan, K., McGinnity, P., Cross, T. F., Crozier, W. W., \& Prodöhl, P. A. (2013). diveRsity: An R package for the estimation and exploration of population genetics parameters and their associated errors. Methods in Ecology and Evolution , 4 (8), 782-788. doi: 10.1111/2041-210X.12067

Klütsch, C. F. C., Manseau, M., \& Wilson, P. J. (2012). Phylogeographical analysis of mtDNA data indicates postglacial expansion from multiple glacial refugia in woodland caribou (Rangifer tarandus caribou). PLOS ONE , 7 (12), e52661. doi: 10.1371/journal.pone.0052661

Lackey, C. W., Beckmann, J. P., \& Sedinger, J. (2013). Bear historical ranges revisited: Documenting the increase of a once-extirpated population in Nevada. The Journal of Wildlife Management ,77 (4), 812-820. doi: $10.1002 /$ jwmg. 548

Lara-Díaz, N. E., Coronel-Arellano, H., Delfín-Alfonso, C. A., Espinosa-Flores, M. E., Peña-Mondragón, J. L., \& López-González, C. A. (2021). Connecting mountains and desert valleys for black bears in northern Mexico. Landscape Ecology . doi: 10.1007/s10980-021-01293-9

Lara-Díaz, N. E., Coronel-Arellano, H., López-González, C. A., Sánchez-Rojas, G., \& Martínez-Gómez, J. E. (2018). Activity and resource selection of a threatened carnivore: The case of black bears in northwestern Mexico. Ecosphere , 9 (1), e01923. doi: 10.1002/ecs2.1923

Liley, S. G., \& Walker, R. N. (2015). Extreme movement by an American black bear in New Mexico and Colorado. Ursus , 26 (1), 1-6. doi: 10.2192/URSUS-D-15-00006.1

Little, A. R., Hammond, A., Martin, J. A., Johannsen, K. L., \& Miller, K. V. (2017). Population growth and mortality sources of the black bear population in northern Georgia. Journal of the Southeastern Association of Fish and Wildlife Agencies , 4, 130-138.

Lomolino, M. V., Brown, J. H., \& Davis, R. (1989). Island biogeograhy of montane forest mammals in the American Southwest. Ecology ,70 (1), 180-194. doi: 10.2307/1938425

Malaney, J. L., Lackey, C. W., Beckmann, J. P., \& Matocq, M. D. (2018). Natural rewilding of the Great Basin: Genetic consequences of recolonization by black bears (Ursus americanus ). Diversity and Distributions , 24 (2), 168-178. doi: 10.1111/ddi.12666

McAuliffe, J. R., \& Van Devender, T. R. (1998). A 22,000-year record of vegetation change in the north-central Sonoran Desert.Palaeogeography, Palaeoclimatology, Palaeoecology , 141 (3), 253-275. doi: 10.1016/S00310182(98)00054-6

McCown, J. W., Kubilis, P., Eason, T. H., \& Scheick, B. K. (2009). Effect of traffic volume on American black bears in central Florida, USA. Ursus , 20 (1), 39-46. doi: 10.2192/08GR004R2.1

McRae, B. H., Dickson, B. G., Keitt, T. H., \& Shah, V. B. (2008). Using circuit theory to model connectivity in ecology, evolution, and conservation. Ecology , 89 (10), 2712-2724. doi: 10.1890/07-1861.1

Messing, H. J. (1986). A Late Pleistocene-Holocene Fauna from Chihuahua, Mexico. The Southwestern Naturalist , 31 (3), 277-288. doi: 10.2307/3671832

Morin, P. A., Martien, K. K., Archer, F. I., Cipriano, F., Steel, D., Jackson, J., \& Taylor, B. L. (2010). Applied conservation genetics and the need for quality control and reporting of genetic data used in fisheries and wildlife management. Journal of Heredity ,101 (1), 1-10. doi: 10.1093/jhered/esp107 
Murphy, S. M., Laufenberg, J. S., Clark, J. D., Davidson, M., Belant, J. L., \& Garshelis, D. L. (2018). Genetic diversity, effective population size, and structure among black bear populations in the Lower Mississippi Alluvial Valley, USA. Conservation Genetics . doi: 10.1007/s10592-018-1075-6

Murphy, S. M., Ulrey, W. A., Guthrie, J. M., Maehr, D. S., Abrahamson, W. G., Maehr, S. C., \& Cox, J. J. (2017). Food habits of a small Florida black bear population in an endangered ecosystem. Ursus ,28 (1), 92-104. doi: 10.2192/URSU-D-16-00031.1

Nystrom, N. A., Levine, M. J., Roskies, R. Z., \& Scott, J. R. (2015). Bridges: A uniquely flexible HPC resource for new communities and data analytics. Proceedings of the 2015 XSEDE Conference: Scientific Advancements Enabled by Enhanced Cyberinfrastructure , 30:1-30:8. New York, NY, USA: ACM. doi: $10.1145 / 2792745.2792775$

Olson, D. M., Dinerstein, E., Wikramanayake, E. D., Burgess, N. D., Powell, G. V. N., Underwood, E. C., ... Kassem, K. R. (2001). Terrestrial ecoregions of the world: A new map of life on Earth.BioScience, 51 (11), 933-938. doi: 10.1641/0006-3568(2001)051[0933:TEOTWA]2.0.CO;2

Omernik, J. M., \& Griffith, G. E. (2014). Ecoregions of the conterminous United States: Evolution of a hierarchical spatial framework. Environmental Management , 54 , 1249-1266. doi: 10.1007/s00267-014-03641

Onorato, D. P., Hellgren, E. C., Mitchell, F. S., \& Skiles, J. R. (2003). Home Range and Habitat Use of American Black Bears on a Desert Montane Island in Texas. Ursus , 14 (2), 120-129. JSTOR. Retrieved from JSTOR.

Onorato, D. P., Hellgren, E. C., Van Den Bussche, R. A., \& Doan-Crider, D. L. (2004). Phylogeographic patterns within a metapopulation of black bears (Ursus americanus) in the American Southwest. Journal of Mammalogy , 85 (1), 140-147.

Onorato, D. P., Hellgren, E. C., Van Den Bussche, R. A., Doan-Crider, D. L., \& Skiles, J. R. (2007). Genetic structure of American black bears in the desert southwest of North America: Conservation implications for recolonization. Conservation Genetics , 8 (3), 565-576. doi: 10.1007/s10592-006-9192-z

Onorato, D. P., Hellgren, E. C., Van Den Bussche, R. A., \& Skiles, Jr., J. R. (2004). Paternity and relatedness of American black bears recolonizing a desert montane island. Canadian Journal of Zoology , 82 (8), 12011210. doi: 10.1139/z04-097

Ostrander, E. A., Sprague, G. F., \& Rine, J. (1993). Identification and characterization of dinucleotide repeat (CA)n markers for genetic mapping in dog. Genomics , 16 (1), 207-213. doi: 10.1006/geno.1993.1160

Paetkau, D. (2003). An empirical exploration of data quality in DNA-based population inventories. Molecular Ecology ,12 (6), 1375-1387. doi: 10.1046/j.1365-294X.2003.01820.x

Paetkau, David, Shields, G. F., \& Strobeck, C. (1998). Gene flow between insular, coastal and interior populations of brown bears in Alaska. Molecular Ecology , 7 (10), 1283-1292. doi: 10.1046/j.1365-294x.1998.00440.x

Paetkau, David, \& Strobeck, C. (1995). The molecular basis and evolutionary history of a microsatellite null allele in bears.Molecular Ecology , 4 (4), 519-520. doi: 10.1111/j.1365-294X.1995.tb00248.x

Pedersen, M. W., De Sanctis, B., Saremi, N. F., Sikora, M., Puckett, E. E., Gu, Z., .. Willerslev, E. (2021). Environmental genomics of Late Pleistocene black bears and giant short-faced bears. Current Biology , 31 (12), 2728-2736.e8. doi: 10.1016/j.cub.2021.04.027

Pelletier, A., Obbard, M. E., Harnden, M., McConnell, S., Howe, E. J., Burrows, F. G., ... Kyle, C. J. (2017). Determining causes of genetic isolation in a large carnivore (Ursus americanus ) population to direct contemporary conservation measures. PLOS ONE , 12 (2), e0172319. doi: 10.1371/journal.pone.0172319

Pelletier, A., Obbard, M. E., White, B. N., Doyle, C., \& Kyle, C. J. (2011). Small-scale genetic structure of American black bears illustrates potential postglacial recolonization routes. Journal of Mammalogy , 92 (3), 
629-644. doi: 10.1644/10-MAMM-A-212.1

Peterman, W. E. (2018). ResistanceGA: An R package for the optimization of resistance surfaces using genetic algorithms. Methods in Ecology and Evolution , 9 (6), 1638-1647. doi: 10.1111/2041-210X.12984

Peterman, W. E., Connette, G. M., Semlitsch, R. D., \& Eggert, L. S. (2014). Ecological resistance surfaces predict fine-scale genetic differentiation in a terrestrial woodland salamander. Molecular Ecology , 23 (10), 2402-2413. doi: 10.1111/mec.12747

Pritchard, J. K. (2000). Inference of population structure using multilocus genotype data. Genetics , 155 (2), 945-959.

Puckett, E. E., Etter, P. D., Johnson, E. A., \& Eggert, L. S. (2015). Phylogeographic Analyses of American Black Bears (Ursus americanus) Suggest Four Glacial Refugia and Complex Patterns of Postglacial Admixture. Molecular Biology and Evolution ,32 (9), 2338-2350. doi: 10.1093/molbev/msv114

R Core Team. (2017). R: A language and environment for statistical computing . R Foundation for Statistical Computing, Vienna, Austria. Retrieved from http://www.R-project.org/.

R Core Team. (2018). R: A language and environment for statistical computing. R Foundation for Statistical Computing, Vienna, Austria. Retrieved from http://www.R-project.org/.

Riley, S. P. D., Serieys, L. E. K., Pollinger, J. P., Sikich, J. A., Dalbeck, L., Wayne, R. K., \& Ernest, H. B. (2014). Individual behaviors dominate the dynamics of an urban mountain lion population isolated by roads. Current Biology , 24 (17), 1989-1994. doi: 10.1016/j.cub.2014.07.029

Rogers, L. L. (1987). Effects of Food Supply and Kinship on Social Behavior, Movements, and Population Growth of Black Bears in Northeastern Minnesota. Wildlife Monographs , (97), 3-72.

Rousset, F., Lopez, J., \& Belkhir, K. (2017). Genepop . Retrieved from https://cran.rproject.org/web/packages/genepop/genepop.pdf

Safner, T., Miller, M. P., McRae, B. H., Fortin, M.-J., \& Manel, S. (2011). Comparison of Bayesian clustering and edge detection methods for inferring boundaries in landscape denetics. International Journal of Molecular Sciences , 12 (2), 865-889. doi: 10.3390/ijms12020865

Saunders. (1977). Lehner Ranch revisited. In Paleoindian Lifeways . The Museum Journal, West Texas Museum Association, Texas Tech University, Lubbock.

Sawaya, M. A., Ramsey, A. B., \& Ramsey, P. W. (2017). American black bear thermoregulation at natural and artificial water sources. Ursus , 27 (2), 129-135. doi: 10.2192/URSU-D-16-00010.1

Serieys, L. E. K., Lea, A., Pollinger, J. P., Riley, S. P. D., \& Wayne, R. K. (2015). Disease and freeways drive genetic change in urban bobcat populations. Evolutionary Applications , 8 (1), 75-92. doi: https://doi.org/10.1111/eva.12226

Shafer, A. B. A., Cullingham, C. I., Côté, S. D., \& Coltman, D. W. (2010). Of glaciers and refugia: A decade of study sheds new light on the phylogeography of northwestern North America. Molecular Ecology , 19 (21), 4589-4621. doi: 10.1111/j.1365-294X.2010.04828.x

Short Bull, R. A., Cushman, S. A., Mace, R., Chilton, T., Kendall, K. C., Landguth, E. L., ... Luikart, G. (2011). Why replication is important in landscape genetics: American black bear in the Rocky Mountains. Molecular Ecology , 20 (6), 1092-1107. doi: https://doi.org/10.1111/j.1365-294X.2010.04944.x

Skinner, M. F. (1942). The fauna of Papago Springs Cave, Arizona, with a study of Stockoceros . Bulletin of the American Museum of Natural History , 80 , 143-220.

Slatkin, M. (1985). Rare Alleles as Indicators of Gene Flow.Evolution , 39 (1), 53-65. doi: https://doi.org/10.1111/j.1558-5646.1985.tb04079.x 
Slaughter, B. H. (1975). Ecological interpretation of the Brown Sand Wedge local fauna. In Late Pleistocene environments of the Southern High Plains (pp. 179-192). Fort Burgwin Research Center Publication.

Sollmann, R., Gardner, B., Belant, J. L., Wilton, C. M., \& Beringer, J. (2016). Habitat associations in a recolonizing, low-density black bear population. Ecosphere, 7 (8), e01406. doi: 10.1002/ecs2.1406

Spaulding, W. G., Betancourt, J. L., Croft, L. K., \& Cole, K. L. (1990). Packrat Middens: Their composition an dmethods of analysis. InPackrat Middens: The Last 40,000 Years of Biotic Change (pp. 59-84). University of Arizona Press, Tucson.

Stone, K. D., Flynn, R. W., \& Cook, J. A. (2002). Post-glacial colonization of northwestern North America by the forest-associated American marten (Martes americana, Mammalia: Carnivora: Mustelidae).Molecular Ecology , 11 (10), 2049-2063. doi: https://doi.org/10.1046/j.1365-294X.2002.01596.x

Sundqvist, L., Keenan, K., Zackrisson, M., Prodöhl, P., \& Kleinhans, D. (2016). Directional genetic differentiation and relative migration.Ecology and Evolution , 6 (11), 3461-3475. doi: 10.1002/ece3.2096

Taberlet, P., Camarra, J.-J., Griffin, S., Uhrès, E., Hanotte, O., Waits, L. P., .. Bouvet, J. (1997). Noninvasive genetic tracking of the endangered Pyrenean brown bear population. Molecular Ecology , 6 (9), 869-876. doi: 10.1111/j.1365-294X.1997.tb00141.x

The Geneland Development Group. (2018). Population genetic and morphometric data analysis using $R$ and the Geneland program .

Thorne, J. H., Choe, H., Stine, P. A., Chambers, J. C., Holguin, A., Kerr, A. C., \& Schwartz, M. W. (2018). Climate change vulnerability assessment of forests in the Southwest USA. Climatic Change ,148 (3), 387-402. doi: $10.1007 / \mathrm{s} 10584-017-2010-4$

Towns, J., Cockerill, T., Dahan, M., Foster, I., Gaither, K., Grimshaw, A., .. Wilkins-Diehr, N. (2014, October). XSEDE: Accelerating scientific discovery. Computing in Science $\mathscr{E}$ Engineering ,16 (5), 62-74.

Van Den Bussche, R. A., Lack, J. B., Onorato, D. P., Gardner-Santana, L. C., McKinney, B. R., Villalobos, J. D., ... Hellgren, E. C. (2009). Mitochondrial DNA phylogeography of black bears (Ursus americanus ) in central and southern North America: Conservation implications. Journal of Mammalogy , 90 (5), 1075-1082. doi: 10.1644/08-MAMM-A-276.1

Van Devender, T. R. (1990a). Late Quaternary vegetation and climate of the Chihuahuan Desert, United States and Mexico. In Packrat Middens: The Last 40,000 Years of Biotic Change (pp. 104-133). University of Arizona Press, Tucson.

Van Devender, T. R. (1990b). Late Quaternary vegetation and climate of the Sonoran Desert, United States and Mexico. In Packrat Middens: The Last 40,000 Years of Biotic Change. University of Arizona Press, Tucson.

Van Etten, J. (2017). R package gdistance: Distances and routes on geographical grids. Journal of Statistical Software . doi: http://dx.doi.org/10.18637/jss.v076.i13

Varas-Nelson, A. C. (2010). Conservation genetics of black bears in Arizona and northern Mexico . University of Arizona, Tucson, Arizona, USA.

Wahlund, S. (1928). The combination of populations and the appearance of correlation examined from the standpoint of the study of heredity.Hereditas , 11, 65-106.

Weckworth, B. V., Talbot, S. L., \& Cook, J. A. (2010). Phylogeography of wolves (Canis lupus ) in the Pacific Northwest. Journal of Mammalogy , 91 (2), 363-375. doi: 10.1644/09-MAMM-A-036.1

Williams, A. P., Allen, C. D., Millar, C. I., Swetnam, T. W., Michaelsen, J., Still, C. J., \& Leavitt, S. W. (2010). Forest responses to increasing aridity and warmth in the southwestern United States.Proceedings of the National Academy of Sciences , 107 (50), 21289-21294. doi: 10.1073/pnas.0914211107 
Zlotin, R. I., \& Parmenter, R. R. (2008). Patterns of mast production in pinyon and juniper woodlands along a precipitation gradient in central New Mexico (Sevilleta National Wildlife Refuge). Journal of Arid Environments , 72 (9), 1562-1572. doi: 10.1016/j.jaridenv.2008.02.021

\section{DATA AVAILABILITY}

Microsatellite data used in this study are available through the Dryad Digital Repository, https://doi.org/10.5061/dryad.fj6q573wn.

\section{AUTHOR CONTRIBUTIONS}

Study design: M.J.G., G.W.R., J.W.C., III.

Funding acquisition: J.W.C., III, G.W.R.

Formal analysis: M.J.G.

Methodology: M.J.G., G.W.R.

Writing - original draft: M.J.G., G.W.R., J.W.C., III,

Writing - review \& editing: M.J.G., G.W.R., J.W.C., III, T.C.A., L.E.H., H.E.J., D.P.O., F.S.W.

Figures 


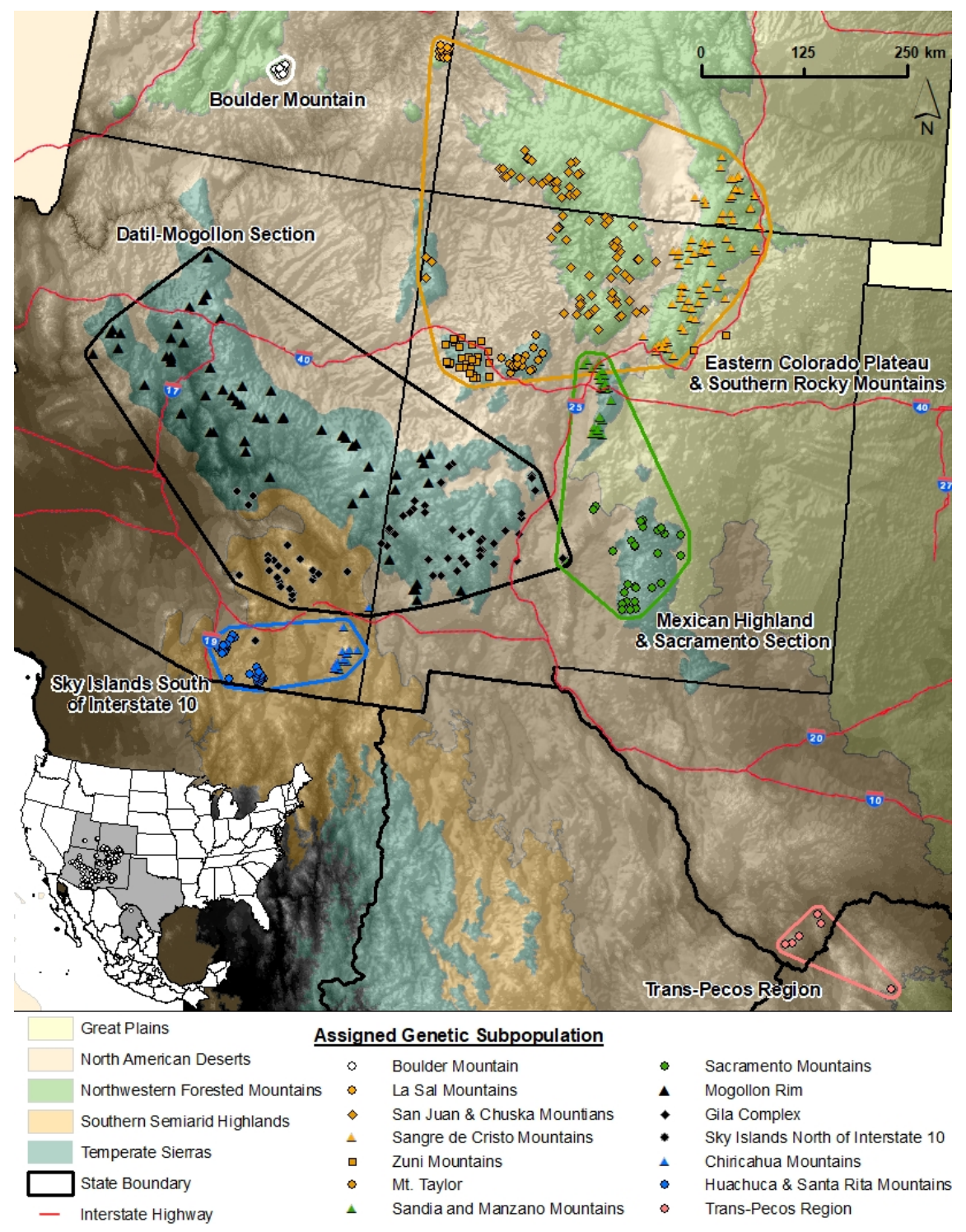

Figure 1. Distribution of genetic samples and subpopulations of American black bears (Ursus americanus ) in the American Southwest and northern Mexico. geneland identified 6 and 14 subpopulations using the uncorrelated (polygons) and correlated (symbols) allele frequency models, respectively. The 6 larger subpopulations are named clusters. 


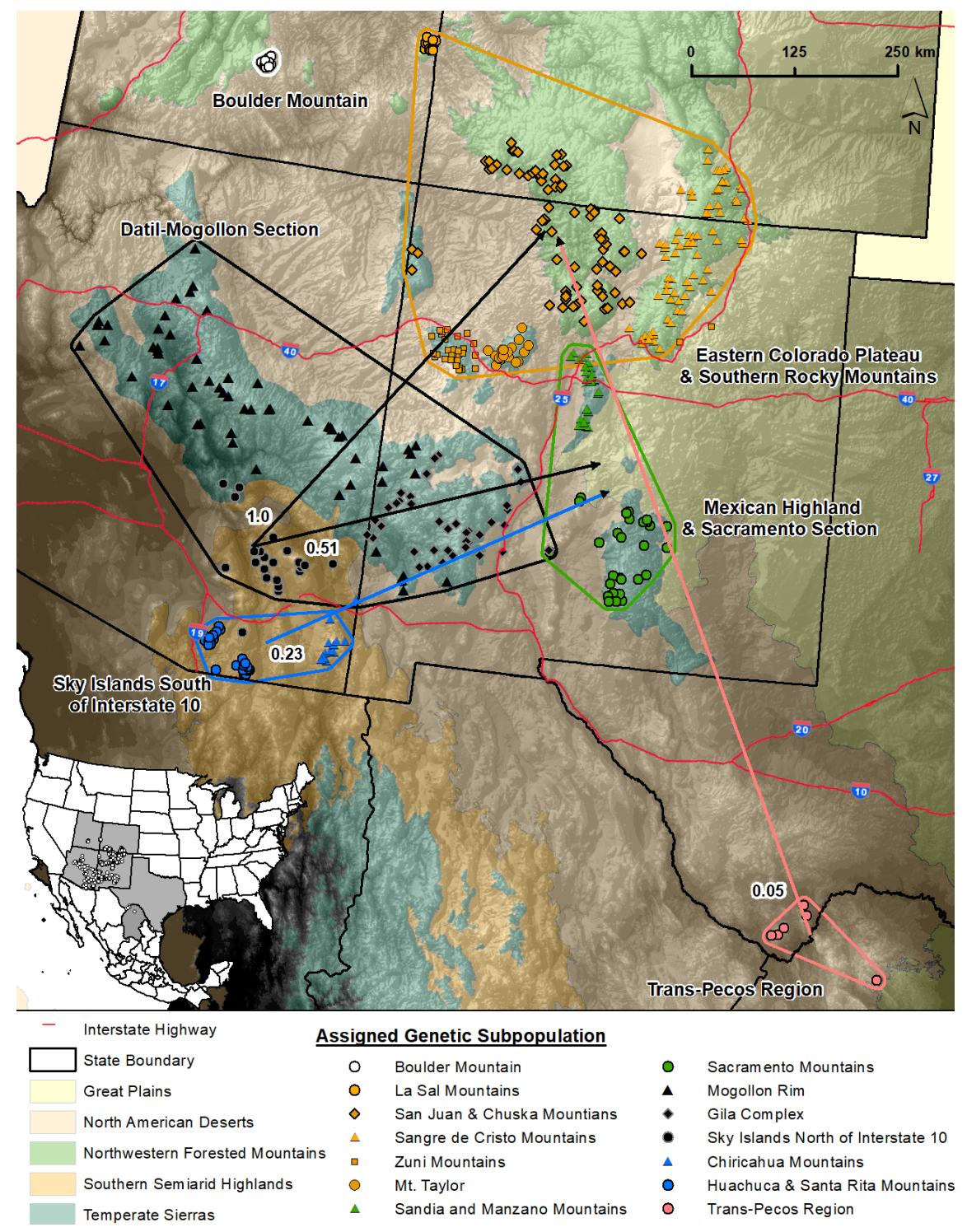

Figure 2. Directional relative migration network based on $\mathrm{G}_{\mathrm{ST}}$ values for American black bear (Ursus americanus ) subpopulations in the American Southwest and northern Mexico. The network visualized shows significant asymmetrical migration values for subpopulations identified using the uncorrelated allele frequency model in program geneland. 


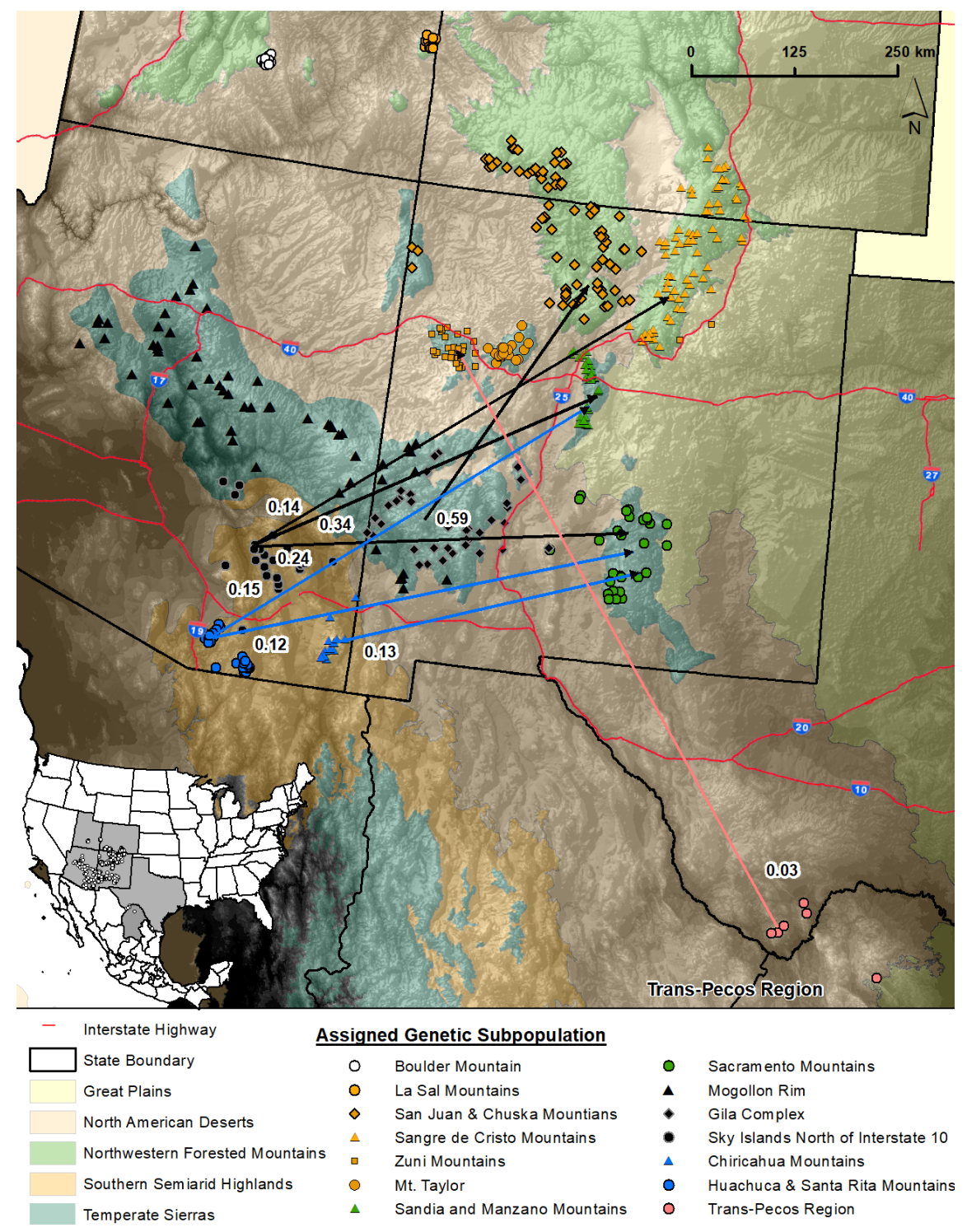

Figure 3. Directional relative migration network based on $\mathrm{G}_{\mathrm{ST}}$ values for American black bear (Ursus americanus ) subpopulations in the American Southwest and northern Mexico. The network visualized shows significant asymmetrical migration values for subpopulations identified using the correlated allele frequency model in program geneland.

Table 1. Number of individuals $(\mathrm{N})$, private alleles $\left(\mathrm{A}_{\mathrm{P}}\right)$, private alleles using rarefaction $\left(\mathrm{A}_{\mathrm{PR}}\right)$, allelic richness using rarefaction $\left(\mathrm{A}_{\mathrm{R}}\right)$, observed $\left(\mathrm{H}_{\mathrm{O}}\right)$ and expected $\left(\mathrm{H}_{\mathrm{E}}\right)$ heterozygosity, and an inbreeding coefficient $\left(\mathrm{F}_{\mathrm{IS}}\right)$ and its $95 \%$ confidence interval (LCI and UCI) based on 1,000 bootstrap iterations for American black bear (Ursus americanus) subpopulations in the American Southwest and northern Mexico.

\begin{tabular}{llllllllll}
\hline Subpopulatibcronym & State & $\mathrm{N}$ & $\mathrm{A}_{\mathrm{P}}$ & $\mathrm{A}_{\mathrm{PR}}$ & $\mathrm{A}_{\mathrm{R}}$ & $\mathrm{H}_{\mathrm{O}}$ & $\mathrm{H}_{\mathrm{E}}$ & $\mathrm{F}_{\mathrm{IS}}$ & LCI \\
\hline $\begin{array}{l}\text { Regional } \\
\begin{array}{l}\text { Boulder } \\
\text { Mountain }\end{array}\end{array}$ & $\mathrm{BT}$ & 21 & 3 & 0.41 & 4.25 & 0.56 & 0.58 & 0.02 & -0.08
\end{tabular}




\begin{tabular}{|c|c|c|c|c|c|c|c|c|c|c|}
\hline Subpopulat & tibcronym & State & $\mathrm{N}$ & $\mathrm{A}_{\mathrm{P}}$ & $\mathrm{A}_{\mathrm{PR}}$ & $A_{R}$ & $\mathrm{H}_{\mathrm{O}}$ & $\mathrm{H}_{\mathrm{E}}$ & $\overline{F_{\text {IS }}}$ & LCI \\
\hline $\begin{array}{l}\text { Eastern } \\
\text { Col- } \\
\text { orado } \\
\text { Plateau } \\
\text { and } \\
\text { South- } \\
\text { ern } \\
\text { Rocky } \\
\text { Mountains }\end{array}$ & ECPSRM & $\mathrm{CO} / \mathrm{NM} / \mathrm{U}$ & JT42 & 8 & 0.26 & 4.61 & 0.48 & 0.50 & 0.04 & 0.01 \\
\hline $\begin{array}{l}\text { Datil- } \\
\text { Mogollon } \\
\text { Section }\end{array}$ & DMS & $\mathrm{AZ} / \mathrm{NM}$ & 247 & 2 & 0.09 & 5.43 & 0.57 & 0.59 & 0.04 & 0.01 \\
\hline $\begin{array}{l}\text { Mexican } \\
\text { High- } \\
\text { land } \\
\text { and } \\
\text { Sacra- } \\
\text { mento } \\
\text { sections }\end{array}$ & MHSS & $\mathrm{NM}$ & 65 & 2 & 0.19 & 4.66 & 0.56 & 0.58 & 0.02 & -0.03 \\
\hline $\begin{array}{l}\text { Sky } \\
\text { Is- } \\
\text { lands } \\
\text { South } \\
\text { of } \\
\text { Inter- } \\
\text { state } \\
10\end{array}$ & SIS & $\mathrm{AZ}$ & 55 & 0 & 0.21 & 3.91 & 0.42 & 0.44 & 0.04 & -0.02 \\
\hline $\begin{array}{l}\text { Trans- } \\
\text { Pecos } \\
\text { region } \\
\text { Mountain } \\
\text { Range }\end{array}$ & $\mathrm{TP}$ & $\mathrm{TX}$ & 20 & 21 & 1.79 & 5.07 & 0.64 & 0.62 & -0.03 & -0.14 \\
\hline $\begin{array}{l}\text { Boulder } \\
\text { Mountain }\end{array}$ & $\mathrm{BM}$ & UT & 21 & 3 & 0.25 & 4.14 & 0.56 & 0.58 & 0.02 & -0.09 \\
\hline $\begin{array}{l}\text { La Sal } \\
\text { Mountains }\end{array}$ & LSM & UT & 28 & 1 & 0.07 & 4.63 & 0.56 & 0.58 & 0.01 & -0.07 \\
\hline $\begin{array}{l}\text { San } \\
\text { Juan } \\
\text { and } \\
\text { Chuska } \\
\text { mountains }\end{array}$ & SJC & $\mathrm{CO} / \mathrm{NM}$ & 82 & 1 & 0.06 & 4.89 & 0.56 & 0.57 & 0.01 & -0.03 \\
\hline $\begin{array}{l}\text { Sangre } \\
\text { de } \\
\text { Cristo } \\
\text { Mountains }\end{array}$ & $\mathrm{SCM}$ & $\mathrm{CO} / \mathrm{NM}$ & 81 & 1 & 0.09 & 4.73 & 0.61 & 0.59 & -0.02 & -0.06 \\
\hline $\begin{array}{l}\text { Zuni } \\
\text { Mountains }\end{array}$ & ZM & $\mathrm{NM}$ & 33 & 0 & 0.04 & 5.01 & 0.54 & 0.53 & 0.00 & -0.07 \\
\hline $\begin{array}{l}\text { Mt. } \\
\text { Taylor }\end{array}$ & MT & $\mathrm{NM}$ & 23 & 1 & 0.03 & 4.36 & 0.55 & 0.54 & 0.00 & -0.11 \\
\hline
\end{tabular}




\begin{tabular}{|c|c|c|c|c|c|c|c|c|c|c|}
\hline Subpopulati & tibaronym & State & $\mathrm{N}$ & $A_{P}$ & $A_{P R}$ & $A_{R}$ & $\mathrm{H}_{\mathrm{O}}$ & $\mathrm{H}_{\mathrm{E}}$ & $\mathrm{F}_{\text {IS }}$ & LCI \\
\hline $\begin{array}{l}\text { Sandia } \\
\text { and } \\
\text { Man- } \\
\text { zano } \\
\text { mountains }\end{array}$ & SMM & NM & 34 & 1 & 0.02 & 4.34 & 0.57 & 0.57 & 0.00 & -0.07 \\
\hline $\begin{array}{l}\text { Mogollon } \\
\text { Rim }\end{array}$ & MR & $\mathrm{AZ}$ & 63 & 0 & 0.01 & 4.26 & 0.50 & 0.52 & 0.03 & -0.02 \\
\hline $\begin{array}{l}\text { Gila } \\
\text { complex }\end{array}$ & GC & NM & 44 & 1 & 0.04 & 3.95 & 0.46 & 0.47 & 0.02 & -0.05 \\
\hline $\begin{array}{l}\text { Sacramenta } \\
\text { Mountains }\end{array}$ & aSM & NM & 31 & 1 & 0.04 & 4.05 & 0.55 & 0.55 & -0.02 & -0.09 \\
\hline $\begin{array}{l}\text { Sky } \\
\text { Is- } \\
\text { lands } \\
\text { North } \\
\text { of } \\
\text { Inter- } \\
\text { state } \\
10\end{array}$ & SIN & $\mathrm{AZ}$ & 35 & 0 & 0.02 & 4.25 & 0.48 & 0.48 & -0.01 & -0.07 \\
\hline $\begin{array}{l}\text { Huachuca } \\
\text { and } \\
\text { Santa } \\
\text { Rita } \\
\text { mountains }\end{array}$ & HSRM & $\mathrm{AZ}$ & 39 & 0 & 0.02 & 3.45 & 0.39 & 0.40 & 0.03 & -0.04 \\
\hline $\begin{array}{l}\text { Chiricahua } \\
\text { complex }\end{array}$ & $\mathrm{CHC}$ & $\mathrm{AZ}$ & 16 & 0 & 0.04 & 3.87 & 0.48 & 0.45 & -0.06 & -0.18 \\
\hline $\begin{array}{l}\text { Trans- } \\
\text { Pecos } \\
\text { region }\end{array}$ & TP & TX & 20 & 21 & 1.39 & 4.89 & 0.64 & 0.62 & -0.03 & -0.13 \\
\hline
\end{tabular}

Table 2. Estimated pairwise genetic differentiation $\left(\mathrm{F}_{\mathrm{ST}}\right)$ and their $95 \%$ confidence intervals based on 1,000 bootstrap iterations for regional subpopulations identified by geneland using the uncorrelated allele frequency model for American black bears (Ursus americanus ) in the American Southwest and northern Mexico. Bolded values signify statistically significant differentiation ( $\mathrm{F}_{\mathrm{ST}}$ [?] 0.05; Hartl \& Clark, 1997).

\begin{tabular}{|c|c|c|c|c|c|c|}
\hline & $\mathrm{BM}$ & ECPSRM & DMS & MHSS & SIS & $\mathrm{TP}$ \\
\hline$\overline{\mathrm{BM}^{\mathrm{a}}}$ & - & & & & & \\
\hline ECPSRM $^{\mathrm{b}}$ & $0.14(0.10-0.17)$ & - & & & & \\
\hline $\mathrm{DMS}^{\mathrm{c}}$ & $0.21(0.17-0.25)$ & $0.03(0.03-0.04)$ & - & & & \\
\hline MHSS $^{d}$ & $0.16(0.12-0.19)$ & $0.04(0.03-0.05)$ & $0.06(0.05-0.08)$ & - & & \\
\hline SIS $^{e}$ & $0.25(0.21-0.29)$ & $0.09(0.08-0.11)$ & $0.09(0.07-0.11)$ & $0.11(0.10-0.13)$ & - & \\
\hline $\mathrm{TP}^{\mathrm{f}}$ & $0.30(0.27-0.34)$ & $0.33(0.31-0.35)$ & $0.40(0.38-0.43)$ & $0.33(0.31-0.36)$ & $0.44(0.42-0.47)$ & - \\
\hline
\end{tabular}

${ }^{\mathrm{a}}$ Boulder Mountain (BM), ${ }^{\mathrm{b}}$ eastern Colorado Plateau and Southern Rocky Mountains (ECPSRM), ${ }^{\mathrm{c}}$ DatilMogollon Section (DMS), dMexican Highland and Sacramento sections (MHSS), e Sky Islands South of Interstate 10 (SIS), ${ }^{\mathrm{f}}$ Trans-Pecos (TP).

Table 3. Estimated pairwise genetic differentiation $\left(\mathrm{F}_{\mathrm{ST}}\right)$ and their $95 \%$ confidence intervals based on 1,000 
bootstrap iterations for mountain range subpopulations identified by geneland using the uncorrelated allele frequency model for American black bears (Ursus americanus ) in the American Southwest and northern Mexico. Bolded values signify statistically significant differentiation ( $\mathrm{F}_{\mathrm{ST}}$ [?] 0.05; Hartl \& Clark, 1997).

\begin{tabular}{|c|c|c|c|c|c|c|c|}
\hline & $\mathrm{BM}$ & LSM & SJC & $\mathrm{SCM}$ & $\mathrm{ZM}$ & $\mathrm{MT}$ & $\mathrm{SMM}$ \\
\hline $\mathrm{BM}^{\mathrm{a}}$ & - & & & & & & \\
\hline $\mathrm{LSM}^{\mathrm{b}}$ & $\begin{array}{l}0.15 \\
(0.11-0.19)\end{array}$ & - & & & & & \\
\hline $\mathrm{SJC}^{\mathrm{c}}$ & $\begin{array}{l}0.15 \\
(0.11-0.19)\end{array}$ & $\begin{array}{l}0.04 \\
(0.02-0.06)\end{array}$ & - & & & & \\
\hline $\mathrm{SCM}^{\mathrm{d}}$ & $\begin{array}{l}0.14 \\
(0.11-0.18)\end{array}$ & $\begin{array}{l}0.05 \\
(0.03-0.07)\end{array}$ & $\begin{array}{l}0.03 \\
(0.02-0.04)\end{array}$ & - & & & \\
\hline $\mathrm{ZM}^{\mathrm{e}}$ & $\begin{array}{l}0.18 \\
(0.13-0.22)\end{array}$ & $\begin{array}{l}0.06 \\
(0.04-0.09)\end{array}$ & $\begin{array}{l}0.03 \\
(0.01-0.04)\end{array}$ & $\begin{array}{l}0.04 \\
(0.03-0.06)\end{array}$ & - & & \\
\hline $\mathrm{MT}^{\mathrm{f}}$ & $\begin{array}{l}0.18 \\
(0.14-0.24)\end{array}$ & $\begin{array}{l}0.08 \\
(0.05-0.11)\end{array}$ & $\begin{array}{l}0.03 \\
(0.01-0.05)\end{array}$ & $\begin{array}{l}0.06 \\
(0.05-0.09)\end{array}$ & $\begin{array}{l}0.04 \\
(0.02-0.08)\end{array}$ & - & \\
\hline $\mathrm{SMM}^{\mathrm{g}}$ & $\begin{array}{l}0.17 \\
(0.13-0.21)\end{array}$ & $\begin{array}{l}0.08 \\
(0.06-0.10)\end{array}$ & $\begin{array}{l}0.04 \\
(0.03-0.06)\end{array}$ & $\begin{array}{l}0.04 \\
(0.03-0.06)\end{array}$ & $\begin{array}{l}0.04 \\
(0.02-0.07)\end{array}$ & $\begin{array}{l}0.04 \\
(0.02-0.06)\end{array}$ & - \\
\hline $\mathrm{MR}^{\mathrm{h}}$ & $\begin{array}{l}0.20 \\
(0.16-0.24)\end{array}$ & $\begin{array}{l}0.09 \\
(0.07-0.11)\end{array}$ & $\begin{array}{l}0.05 \\
(0.04-0.06)\end{array}$ & $\begin{array}{l}0.06 \\
(0.05-0.08)\end{array}$ & $\begin{array}{l}0.02 \\
(0.01-0.03)\end{array}$ & $\begin{array}{l}0.05 \\
(0.03-0.09)\end{array}$ & $\begin{array}{l}0.06 \\
(0.05-0.08)\end{array}$ \\
\hline $\mathrm{GC}^{\mathrm{i}}$ & $\begin{array}{l}0.23 \\
(0.19-0.27)\end{array}$ & $\begin{array}{l}0.09 \\
(0.07-0.12)\end{array}$ & $\begin{array}{l}0.05 \\
(0.04-0.06)\end{array}$ & $\begin{array}{l}0.07 \\
(0.06-0.09)\end{array}$ & $\begin{array}{l}0.02 \\
(0.01-0.04)\end{array}$ & $\begin{array}{l}0.06 \\
(0.04-0.09)\end{array}$ & $\begin{array}{l}0.06 \\
(0.04-0.09)\end{array}$ \\
\hline $\mathrm{SM}^{\mathrm{j}}$ & $\begin{array}{l}0.16 \\
(0.13-0.21)\end{array}$ & $\begin{array}{l}0.10 \\
(0.08-0.12)\end{array}$ & $\begin{array}{l}0.07 \\
(0.06-0.09)\end{array}$ & $\begin{array}{l}0.08 \\
(0.07-0.10)\end{array}$ & $\begin{array}{l}0.09 \\
(0.06-0.12)\end{array}$ & $\begin{array}{l}0.07 \\
(0.05-0.09)\end{array}$ & $\begin{array}{l}0.04 \\
(0.02-0.07)\end{array}$ \\
\hline $\operatorname{SIN}^{k}$ & $\begin{array}{l}0.20 \\
(0.16-0.24)\end{array}$ & $\begin{array}{l}0.09 \\
(0.07-0.11)\end{array}$ & $\begin{array}{l}0.06 \\
(0.04-0.07)\end{array}$ & $\begin{array}{l}0.07 \\
(0.05-0.08)\end{array}$ & $\begin{array}{l}0.03 \\
(0.01-0.04)\end{array}$ & $\begin{array}{l}0.07 \\
(0.04-0.10)\end{array}$ & $\begin{array}{l}0.07 \\
(0.05-0.09)\end{array}$ \\
\hline $\mathrm{HSRM}^{1}$ & $\begin{array}{l}0.27 \\
(0.23-0.32)\end{array}$ & $\begin{array}{l}0.15 \\
(0.13-0.18)\end{array}$ & $\begin{array}{l}0.14 \\
(0.13-0.16)\end{array}$ & $\begin{array}{l}0.13 \\
(0.12-0.15)\end{array}$ & $\begin{array}{l}0.12 \\
(0.10-0.15)\end{array}$ & $\begin{array}{l}0.16 \\
(0.13-0.19)\end{array}$ & $\begin{array}{l}0.13 \\
(0.11-0.16)\end{array}$ \\
\hline $\mathrm{CHC}^{\mathrm{m}}$ & $\begin{array}{l}0.22 \\
(0.18-0.27)\end{array}$ & $\begin{array}{l}0.11 \\
(0.09-0.14)\end{array}$ & $\begin{array}{l}0.10 \\
(0.07-0.12)\end{array}$ & $\begin{array}{l}0.09 \\
(0.07-0.12)\end{array}$ & $\begin{array}{l}0.07 \\
(0.05-0.11)\end{array}$ & $\begin{array}{l}0.13 \\
(0.09-0.18)\end{array}$ & $\begin{array}{l}0.11 \\
(0.08-0.14)\end{array}$ \\
\hline $\mathrm{TP}^{\mathrm{n}}$ & $\begin{array}{l}0.30 \\
(0.27-0.34)\end{array}$ & $\begin{array}{l}0.33 \\
(0.30-0.37)\end{array}$ & $\begin{array}{l}0.34 \\
(0.32-0.37)\end{array}$ & $\begin{array}{l}0.32 \\
(0.30-0.35)\end{array}$ & $\begin{array}{l}0.37 \\
(0.33-0.40)\end{array}$ & $\begin{array}{l}0.36 \\
(0.33-0.40)\end{array}$ & $\begin{array}{l}0.34 \\
(0.32-0.37)\end{array}$ \\
\hline
\end{tabular}

${ }^{\mathrm{a}}$ Boulder Mountain (BM), ${ }^{\mathrm{b}}$ La Sal Mountains (LSM), ${ }^{\mathrm{c}}$ San Juan and Chuska mountains (SJC), ${ }^{\mathrm{d}}$ Sangre de Cristo Mountains (SCM), ${ }^{\text {e }}$ Zuni Mountains (ZM), ${ }^{\mathrm{f}}$ Mt. Taylor (MT), ${ }^{g}$ Sandia and Manzano mountains $(\mathrm{SMM}),{ }^{\mathrm{h}}$ Mogollon Rim (MR), ${ }^{\mathrm{i}}$ Gila complex (GC), ${ }^{\mathrm{j}}$ Sacramento Mountains (SM), ${ }^{\mathrm{k}}$ Sky Islands north of Interstate 10 (SIN), ${ }^{1}$ Huachuca and Santa Rita mountains (HSRM), ${ }^{m}$ Chiricahua complex (CHC), ${ }^{\mathrm{n}}$ Trans-Pecos region (TP).

\begin{tabular}{|c|c|c|c|c|c|c|c|}
\hline & $\mathrm{MR}$ & GC & $\mathrm{SM}$ & SIN & HSRM & $\mathrm{CHC}$ & $\mathrm{TP}$ \\
\hline \multicolumn{8}{|l|}{$\overline{\mathrm{BM}^{\mathrm{a}}}$} \\
\hline \multicolumn{8}{|l|}{$\mathrm{LSM}^{\mathrm{b}}$} \\
\hline \multicolumn{8}{|l|}{$\mathrm{SJC}^{\mathrm{c}}$} \\
\hline \multicolumn{8}{|l|}{$\mathrm{SCM}^{\mathrm{d}}$} \\
\hline \multicolumn{8}{|l|}{$\mathrm{ZM}^{\mathrm{e}}$} \\
\hline \multicolumn{8}{|c|}{$\mathrm{MT}^{\mathrm{f}}$} \\
\hline \multicolumn{8}{|c|}{$\mathrm{SMM}^{\mathrm{g}}$} \\
\hline $\mathrm{MR}^{\mathrm{h}}$ & - & & & & & & \\
\hline $\mathrm{GC}^{\mathrm{i}}$ & $\begin{array}{l}0.01 \\
(0.00-0.03)\end{array}$ & - & & & & & \\
\hline
\end{tabular}




\begin{tabular}{|c|c|c|c|c|c|c|c|}
\hline & $\mathrm{MR}$ & $\mathrm{GC}$ & SM & SIN & HSRM & $\mathrm{CHC}$ & $\mathrm{TP}$ \\
\hline $\mathrm{SM}^{\mathrm{j}}$ & $\begin{array}{l}0.09 \\
(0.07-0.11)\end{array}$ & $\begin{array}{l}0.11 \\
(0.08-0.13)\end{array}$ & - & & & & \\
\hline SIN $^{k}$ & $\begin{array}{l}0.02 \\
(0.00-0.04)\end{array}$ & $\begin{array}{l}0.03 \\
(0.02-0.06)\end{array}$ & $\begin{array}{l}0.09 \\
(0.07-0.12)\end{array}$ & - & & & \\
\hline $\mathrm{HSRM}^{1}$ & $\begin{array}{l}0.12 \\
(0.10-0.15)\end{array}$ & $\begin{array}{l}0.15 \\
(0.12-0.18)\end{array}$ & $\begin{array}{l}0.17 \\
(0.14-0.20)\end{array}$ & $\begin{array}{l}0.10 \\
(0.08-0.13)\end{array}$ & - & & \\
\hline $\mathrm{CHC}^{\mathrm{m}}$ & $\begin{array}{l}0.08 \\
(0.05-0.12)\end{array}$ & $\begin{array}{l}0.09 \\
(0.05-0.13)\end{array}$ & $\begin{array}{l}0.13 \\
(0.10-0.16)\end{array}$ & $\begin{array}{l}0.06 \\
(0.03-0.10)\end{array}$ & $\begin{array}{l}0.08 \\
(0.05-0.12)\end{array}$ & - & \\
\hline $\mathrm{TP}^{\mathrm{n}}$ & $\begin{array}{l}0.38 \\
(0.36-0.41)\end{array}$ & $\begin{array}{l}0.41 \\
(0.38-0.45)\end{array}$ & $\begin{array}{l}0.34 \\
(0.31-0.37)\end{array}$ & $\begin{array}{l}0.40 \\
(0.38-0.44)\end{array}$ & $\begin{array}{l}0.46 \\
(0.43-0.49)\end{array}$ & $\begin{array}{l}0.40 \\
(0.37-0.43)\end{array}$ & - \\
\hline
\end{tabular}

Table 3 continued. Estimated pairwise genetic differentiation $\left(\mathrm{F}_{\mathrm{ST}}\right)$ and their $95 \%$ confidence intervals based on 1,000 bootstrap iterations for mountain range subpopulations identified by geneland using the uncorrelated allele frequency model for American black bears (Ursus americanus ) in the American Southwest and northern Mexico. Bolded values signify statistically significant differentiation (FST [?] 0.05; Hartl \& Clark, 1997).

${ }^{a}$ Boulder Mountain (BM), ${ }^{\mathrm{b}}$ La Sal Mountains (LSM), ${ }^{\mathrm{c}}$ San Juan and Chuska mountains (SJC), ${ }^{\mathrm{d}}$ Sangre de Cristo Mountains (SCM), ${ }^{\text {e }}$ Zuni Mountains (ZM), ${ }^{\mathrm{f}}$ Mt. Taylor (MT), ${ }^{\mathrm{g}}$ Sandia and Manzano mountains $(\mathrm{SMM}),{ }^{\mathrm{h}}$ Mogollon Rim (MR), ${ }^{\mathrm{i}}$ Gila complex (GC), ${ }^{\mathrm{j}}$ Sacramento Mountains (SM), ${ }^{\mathrm{k}}$ Sky Islands north of Interstate 10 (SIN), ${ }^{l}$ Huachuca and Santa Rita mountains (HSRM), ${ }^{m}$ Chiricahua complex (CHC), ${ }^{\mathrm{n}}$ Trans-Pecos region (TP).

Table 4. Model selection results for 2 optimization runs derived using Akaike's Information Criterion corrected for small sample size $\left(\mathrm{AIC}_{\mathrm{c}}\right)$ comparing the top-ranked resistance surface optimized using linear mixed-effects models with maximum likelihood population effects parameterization to models compared to those composed of Euclidean distance (Distance Only) and Euclidean plus the top-ranked resistance surface (Top resistance surface + Distance). We ranked models by the difference in $\mathrm{AIC}_{\mathrm{c}}\left(\Delta \mathrm{AIC}_{\mathrm{c}}\right)$ between the top model and competing models and evaluated model support using model weights $\left(w_{i}\right)$. Optimization results are also reported including the percent contribution of each covariate to the total surface resistance (Contribution), transformation applied to each covariate (Transformation) along with the shape and magnitude of each transformed covariate.

\begin{tabular}{|c|c|c|c|c|c|c|}
\hline Model & $\mathrm{AIC}_{\mathrm{c}}$ & $\Delta \mathrm{AIC}_{\mathrm{c}}$ & $w_{i}$ & Contribution & Transformation Shape & Magnitude \\
\hline \multicolumn{7}{|c|}{$\begin{array}{l}\text { Optimization } \\
\text { run } 1\end{array}$} \\
\hline $\begin{array}{l}\text { Top } \\
\text { resistance } \\
\text { surface + } \\
\text { Distance }\end{array}$ & -388853.00 & 0.00 & 1.00 & - & - & - \\
\hline $\begin{array}{l}\text { Top } \\
\text { resistance } \\
\text { surface }\end{array}$ & -387083.80 & 1769.20 & 0.00 & - & - & - \\
\hline $\begin{array}{l}\text { Canopy } \\
\text { height }\end{array}$ & - & - & & 40 & $\begin{array}{l}\text { Inverse } 0.51 \\
\text { Monomolecular }\end{array}$ & 1272.21 \\
\hline Precipitation & - & - & & 58 & $\begin{array}{l}\text { Inverse } \\
\text { Ricker }\end{array}$ & 1585.36 \\
\hline $\begin{array}{l}\text { Terrain } \\
\text { ruggedness } \\
\text { index }\end{array}$ & - & - & & 02 & Monomolecular 2.87 & 318.72 \\
\hline
\end{tabular}




\begin{tabular}{|c|c|c|c|c|c|c|}
\hline Model & $\mathrm{AIC}_{\mathrm{c}}$ & $\Delta \mathrm{AIC}_{\mathrm{c}}$ & $w_{i}$ & Contribution & Transformation Shape & Magnitude \\
\hline $\begin{array}{l}\text { Distance } \\
\text { Only } \\
\text { Optimizatio } \\
\text { run } 2\end{array}$ & -378750.20 & 10102.80 & 0.00 & - & - & - \\
\hline $\begin{array}{l}\text { Top } \\
\text { resistance } \\
\text { surface }+ \\
\text { Distance }\end{array}$ & -388853.00 & 0.00 & 1.00 & - & - & - \\
\hline $\begin{array}{l}\text { Top } \\
\text { resistance } \\
\text { surface }\end{array}$ & -387096.20 & 1756.80 & 0.00 & - & - & - \\
\hline $\begin{array}{l}\text { Canopy } \\
\text { height }\end{array}$ & - & - & & 40 & $\begin{array}{l}\text { Inverse } 0.51 \\
\text { Monomolecular }\end{array}$ & 1272.21 \\
\hline Precipitation & - & - & & 58 & $\begin{array}{l}\text { Inverse } \\
\text { Ricker }\end{array}$ & 1585.36 \\
\hline $\begin{array}{l}\text { Terrain } \\
\text { ruggedness } \\
\text { index }\end{array}$ & - & - & & 02 & Monomolecular 2.87 & 318.72 \\
\hline $\begin{array}{l}\text { Distance } \\
\text { Only }\end{array}$ & -378750.20 & 10102.80 & 0.00 & - & - & - \\
\hline
\end{tabular}

